\title{
Petrogenesis of Permian alkaline lamprophyres and diabases from the Spanish Central System and their geodynamic context within western Europe
}

\author{
D. Orejana • C. Villaseca $\cdot$ K. Billström • \\ B. A. Paterson
}

\begin{abstract}
Basic to ultrabasic alkaline lamprophyres and diabases intruded within the Spanish Central System (SCS) during Upper Permian. Their high LREE, LEE and HFSE contents, together with positive $\mathrm{Nb}-\mathrm{Ta}$ anømalies, link their origin with the infiltration of sublithospheric K-rich fluids. These alkaline dykes may be classified in twe distinct grøups according to the Sr-Nd isøtøpe ratios: (1) a depleted PREMA-like asthenospheric component, and (2) a BSE-like lithospheric component. A slight enrichment in radiegenic ${ }^{207} \mathrm{~Pb}$ and ${ }^{208} \mathrm{~Pb}$ allows the contribution of a recycled crustal or lithospheric component in the mantle sources. The intrusion of this alkaline magmatism is likely to have occurred due to adiabatic decompression and mantle upwelling in the context of the widespread rifting developed from Carboniferøus to Permian in western Europe. The clear differences in the ge chemical affinity of Lower Permian basic magmas from north-western and south-western Europe might be interpreted in terms of a more extensive separation of both regions during that period, until they were assembled during Upper Permian.
\end{abstract}

Keywords Lamprophyres - Alkaline magmatism Asthenospheric mantle Permian rifting - Western Eurøpe

\section{Introduction}

Alkaline lamprophyres are considered tø be the equivalent - basaltic rocks with high volatile contents, being related to partial melting of a hydrated mantle enriched in incompatible elements (Rock 1991). The incorporation of volatiles is thøught to be due t• metas matism by infilrating fluids or silicate melts ascending frøm lithospheric or sub-lithospheric sources (e.g. Hawkesworth et al. 1990).

Mafic alkaline lamprophyres were intruded during the Upper Permian in the Spanish Central System (SCS). Other moderately alkaline rocks from the Iberian Peninsula are broadly coeval with these lamprophyres (mafic dykes from Pyrenees; Debon and Zimmermann 1993), or are very similar in age (North Portugal; Portugal-Ferreira and

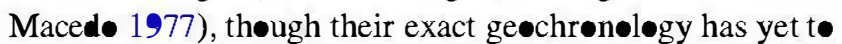
be constrained. In any case, this intraplate magmatism represents a small volume of intruded magma. Previøus studies, which focused on the Permø-Carboniferøus magmatism from central Spain (Perini et al. 2004) and on the Hercynian and post-Hercynian basic rocks of the SCS (Bea et a1. 1999), have advocated a lithospheric origin for the mantle sources of the SCS alkaline lamprophyres. Other studies have reveale that part of the SCS Permian alkaline basic intusions show an is topically depleted component, indicative of greater heterogeneity than previously suggested and the involvement of sub-lithospheric sources (Villaseca et al. 2004; Orejana et al. 2005).

The geodynamic setting proposed for these dyke swarms is als the subject of debate. Søme authors link their generation to manifestations of Perm॰-Carbøniferøus 
magmatism related the impingement of a mantle plume priør to the opening of the Atlantic Ocean (D॰blas et al. 1998; Perini et al. 2004), whereas others consider that rifting in this region could result from lithosphere thinning and adiabatic upwelling of the hot asphenosphere (Orejana et al. 2006).

In this study we present new data, including major and trace element mineral analyses, bulk-rock composition and is tope ratios ( $\mathrm{Sr}-\mathrm{Nd}-\mathrm{Pb}$ ), which allow us to elucidate the petrogenesis of these alkaline dykes. The new sample set covers the whole outcropping region of every dyke swarm, and considerably enlarging the previously available analytical dataset. Particular emphasis is placed on the heterogeneity of the mantle sources, the possible role of crustal components and on the nature of any metasomatising agents. Furthermøre, we als discuss the significance of the gechemical differences that exist in the widespread Permian basic magmatism developed at the end of the Hercynian orogeny in north-western and south-western Europe.

\section{Geological setting}

The SCS is located within the Central-Iberian Zone of the Iberian Massif (Fig. 1). This is a large batholith that consists of several granitic bødies emplaced int Palae -

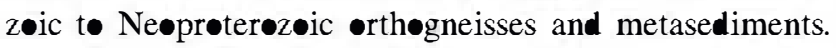
The first manifestation of this granite magmatism has been dated at $346 \pm 63 \mathrm{Ma}$ (Villaseca et al. 1998a), approximately $50 \mathrm{Ma}$ after the beginning of the Hercynian collision (408-387 Ma; Gutiérrez Marcø et al. 1990). In velume terms the most important plutons were emplaced in the range 323-284 Ma (Villaseca et al. 1998b; Bea et a1. 1999; Zeck et a1. 2007). The SCS Hercynian granitoids are mainly peraluminous felsic varieties displaying a narrow compositional range, and which do not show any marked compositional trend with time (Villaseca and Herreros 2000).

Hercynian basic intrusions in the SCS are volumetrically small and eccur as small gabbrøic to quartz-dioritic masses. Ages range from $322 \pm 5 \mathrm{Ma}(\mathrm{Rb}-\mathrm{Sr}$ whøle-røck is chron; Casillas et al. 1991) to $306 \pm 2 \mathrm{Ma}$ (SMS U-Pb dating of zircon; Zeck et al. 2007). Based on their ge•chemisty these rocks have been linked to crustal recycling in the mantle or melting of a subduction-modified mantle source (Villaseca et a1. 2004). In addition to these minor basic intrusives, the SCS is cross-cut by a number of different post-collisional dyke swarms (Fig. 1): (1) E-W oriented calc-alkaline microdiorites $(290 \pm 10 \mathrm{Ma}, \mathrm{Rb}-\mathrm{Sr}$

Fig. 1 Schematic map showing the Permian alkaline lamprophyres and diabases from the SCS, together with other post-collisional magmatic intrusions of calc-alkaline and tholeiitic affinity. The names of the nine dyke swarms sampled in this study are indicated in italics

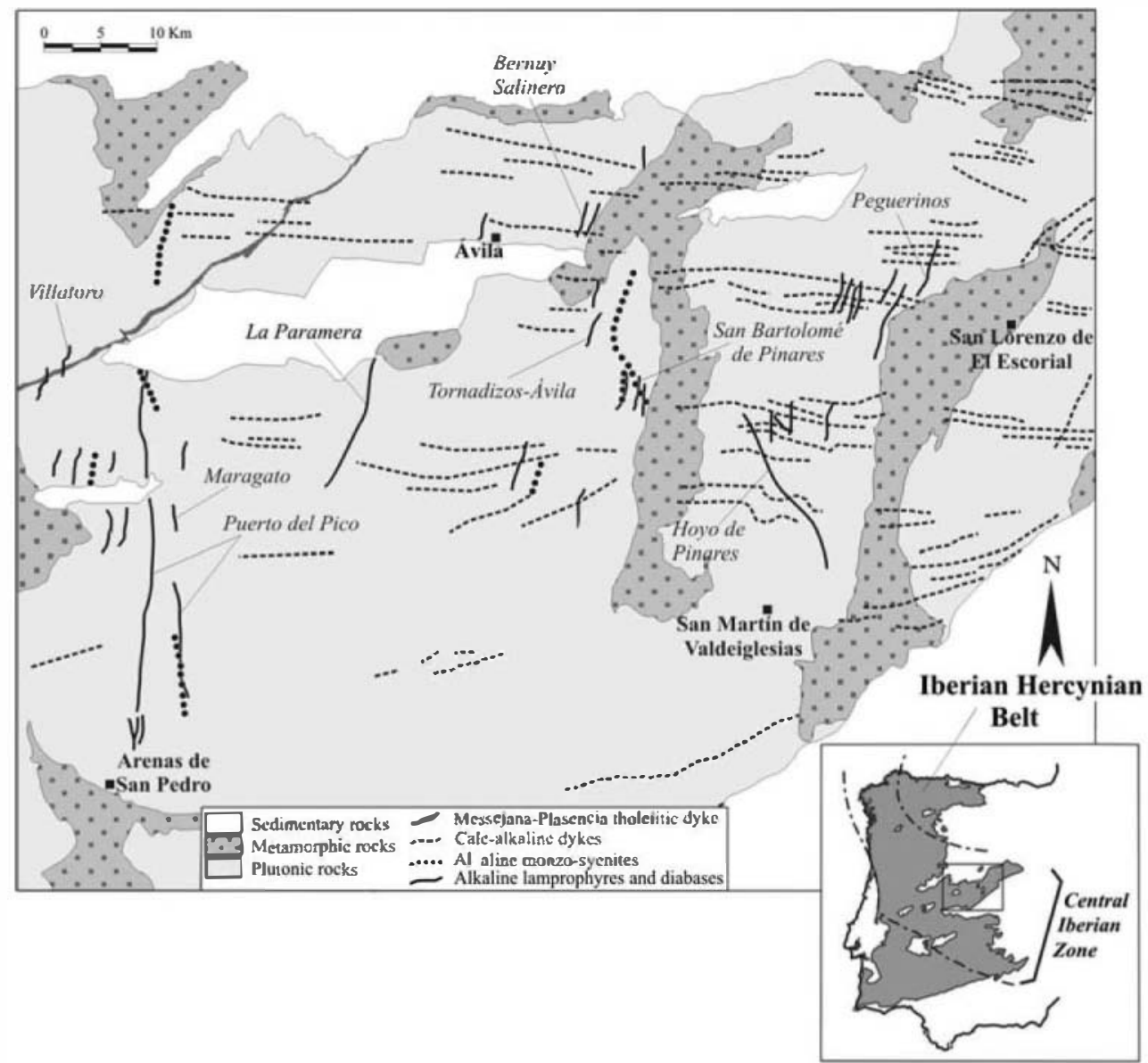


isøchrøn; Galind॰ et a1. 1994), (2) shøshønitic micrøgabbrøs, and (3) N-S oriented alkaline dykes. The first tw• sets are associate with coeval granite porphyries. These three dyke swarm sets have been classified by Villaseca et a1. (2004) int• the følløwing grøupings, Gb2, Gb3 and $\mathrm{Gb} 4$, respectively. The Gbl group was assigned to the previøusly mentiøned Hercynian gabbrøic t• quartz-diøritic masses. The last magmatic event recorded in the SCS is represented by the intrusion of the large gabbroic Messejana-Plasencia theleiitic dyke (named Gb5 by Villaseca et al. 2004), ate at $203 \pm 2 \mathrm{Ma}$ ( $\mathrm{Ar}-\mathrm{Ar}$ in bi tite; Dunn et a1. 1998), which is linked to the •pening of the Atlantic Ocean.

The alkaline suite (Gb4 grøup) may be further subdivided into: (1) basic to ultrabasic lamprophyres and diabases, and (2) monz@gabbrøic t• syenitic pørphyries. The møst recent geøchronøløgical data $\bullet$ btained for these rocks give Upper Permian intrusive ages between $264 \pm 1 \mathrm{Ma}$ (Ar-Ar on amphibøle frøm lamprophyre dykes; Perini et al. 2004; Scarrow et al. 2006) and $252 \pm 3 \mathrm{Ma}$ (U-Pb on zircon from a syenitic pørphyry; Fernández Suárez et a1. 2006). The lamprophyres carry xenøcrysts and megacrysts (mainly clinøpyrøxene, amphibøle and plagiøclase), and alse xenøliths that are relatively abundant in some outcrops. The latter can be brøadly subdivided int• granulite and ulramafic xenøliths. Møst $\bullet$ the SCS granulites have been interpreted as lower crustal restites formed as the result of extraction of the granite melts which led to the formation of the SCS bath-

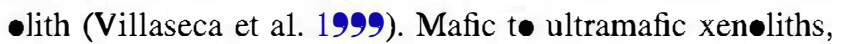
-n the contrary, are deep pyroxenitic cumulates that crystallised directly from Permian alkaline basic magmas or melts related t• Hercynian calc-alkaline mafic underplating events (Orejana et al. 2006).

\section{Analytical methods}

The majør element composition of minerals from SCS alkaline lamprophyres and diabases were determined the Centro de Microscopía Electrónica "Luis Bru" (Complutentse University of Madrid) using a Jeøl JZA-8900 M electron micrøprobe with four wavelength dispersive spectrometers. Accelerating vøltage was $15 \mathrm{kV}$ and the electron beam current $20 \mathrm{nA}$, with a beam diameter of $5 \mu \mathrm{m}$. Elements were counted for $10 \mathrm{~s}$ on the peak and $5 \mathrm{~s}$

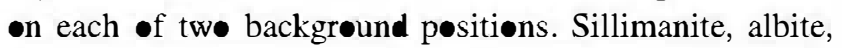
almandine, kaersutite, microcline, ilmenite, fluørapatite, scap॰lite, Ni alløy, crømite, gahnite, bentønite and strøntianite mineral standards were employed. Corrections were made using the ZAF methed.

Trace element compositions (REE, $\mathrm{Ba}, \mathrm{Rb}, \mathrm{Pb}, \mathrm{Th}, \mathrm{U}$, $\mathrm{Nb}, \mathrm{Ta}, \mathrm{Sr}, \mathrm{Zr}, \mathrm{Hf}, \mathrm{Y}, \mathrm{Cr}, \mathrm{Ni}, \mathrm{V}$ and $\mathrm{Sc}$ ) were determined in situ $\bullet n>130 \mu \mathrm{m}$ thick pølished sections by laser ablation (LA-ICP-MS) at the University of Brist using a VG Elemental Plasma Quad 3 ICP-MS coupled t• a VG LaserPrøbe II $(266 \mathrm{~nm}$ frequency-quadrupled Nd-YAG laser). Each analysis consisted of $100 \mathrm{~s} \bullet$ of counting time (including $40 \mathrm{~s} \bullet$ background measurement), using a laser beam with a diameter of arøund $20 \mu \mathrm{m}$. NIST 610 glass was used for instrument calibration, and NIST 612 was used as a secondary standard (results are shøwn in eTable 1). Each analysis was normalised t• $\mathrm{Ca}$ (clinøpyrøxene, amphib॰le, apatite) or Si (feldspars, phløg॰pite), using concentrations determined by electron micrøprøbe.

Føurteen new whole rock samples were analysed at the CNRS-CRPG Nancy for whøle røck majør and trace elements, adding to the existing seven dyke analyses (Villaseca et al. 2004; Orejana et al. 2006). The samples were fused using $\mathrm{LiB} \bullet_{2}$ and dissølved with $\mathrm{HNO}_{3}$. Sølutions were analysed by inductively coupled plasma at $\bullet$ mic emissiøn spectrømetry (ICP-AES) for majør elements, whilst trace elements have been determined by ICP mass spectrometry (ICP-MS). Uncertainties in majør elements range frøm 1 t• $3 \%$, excepting $\mathrm{Mn} \bullet(5-1 \bullet \%)$ and $\mathrm{P}_{2} \bullet_{5}$ $(>10 \%)$. Carignan et al. (2001) have evaluated the precisiøn $\bullet$ Nancy ICP-MS analyses at løw concentration levels from repeated analysis of the international standards BR, $\mathrm{DR}-\mathrm{N}, \mathrm{UB}-\mathrm{N}, \mathrm{AN}-\mathrm{G}$ and $\mathrm{GH}$. The precision for $\mathrm{Rb}, \mathrm{Sr}, \mathrm{Zr}$, $\mathrm{Y}, \mathrm{V}, \mathrm{Ga}, \mathrm{Hf}$ and most $\bullet$ the REE is in the range $1-5 \%$, whereas they range frøm 5 t॰ $10 \%$ for the rest of trace elements, including Tm. Analyses of BR (an independent standard) are shown in eTable 1.

$\mathrm{Pb}$ is otope ratios have been determined on seven lamprophyres and diabases and tw• hornblenditic xen॰liths (previøusly analysed for Sr-Nd is et a1. 2004; Orejana et al. 2006) at the Labøratory •f Isøtope Geølogy of the Natural History Museum of Støckh॰lm. These samples were dissølved using a 10:1 mixture of $\mathrm{HF}$ and $\mathrm{HN}_{3}$ according to røutine prøcedures -f the labøratory. $\mathrm{Pb}$ was separated from the samples using element specific iøn-exchange columns. The samples were spiked with a ${ }^{205} \mathrm{~Pb}$ tracer sølution of knøwn concentration to determine the lead concentrations. Is tope ratiøs were measure using a Finnigan MAT 261 multic llector TMS in static mode. Empirical measurements of mass fractionation as a function of temperature were established using the international $\mathrm{Pb}$ is tope standards NBS 981 and NBS 982. Data from unknown samples, when corrected in an analøgous way, are reproducible and accurate within $0.1 \%$ (Table 4) and analyses of BCR-1 gave results $\left({ }^{206} \mathrm{~Pb} /{ }^{204} \mathrm{~Pb}=18.79,{ }^{207} \mathrm{~Pb} /{ }^{204} \mathrm{~Pb}=15.63,{ }^{208} \mathrm{~Pb} /{ }^{204} \mathrm{~Pb}=\right.$ 38.74) in agreement with literature values $\left({ }^{206} \mathrm{~Pb} /{ }^{204} \mathrm{~Pb}=\right.$ $18.81,{ }^{207} \mathrm{~Pb} /{ }^{204} \mathrm{~Pb}=15.62,{ }^{208} \mathrm{~Pb} / 204 \mathrm{~Pb}=38.70$ ).

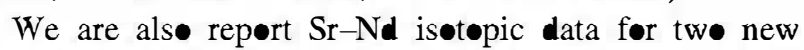
lamprophyre samples. These were determined at the 
Southamptøn Oceanøgraphy Centre, using a VG Sector 54 multi-collector TMS with data acquired in multidynamic mode. Is topic ratios of $\mathrm{Sr}$ and Nd were measured on a subsample of whøle rock powder. Repeated analysis of NBS 987 gave ${ }^{87} \mathrm{Sr} /{ }^{86} \mathrm{Sr}=\mathbf{0 . 7 1 0 2 4 5} \pm 06(2 \sigma)$ and the ${ }^{143} \mathrm{Nd} /{ }^{144} \mathrm{Nd}$ ratie of the JM Nd standard was $0.511856 \pm 05(2 \sigma)$.

\section{Petrography}

The SCS alkaline lamprophyres and diabases display a heterogeneous porphyritic texture with abundant mafic phenocrysts (clinopyroxene, kaersutite, -livine pseud•morphs, phlogøpite, ulvospinel). Nevertheless, the relative abundance and distribution of these minerals varies significantly from one dyke to another. Following the criteria of Le Maitre et al. (2002) we can classify the SCS lamprophyric dykes (leaving aside diabases) as camptonites, due the abundance of clinopyroxene, amphibøle and phlogøite phenocrysts, absence of felsic phenocrysts and predominance of plagioclase over alkali feldspar within the grøundmass. N• glass has been føund.

Mafic dykes als carry deep-crystallised megacrysts (clinøpyroxene, amphibøle and plagiøclase), which are more abundant in the diabase dykes, and xenøliths of distinctive provenance (wall-røck, lower crustal granulites and pyroxenite xenoliths from the upper mantle-lower crust boundary) (Villaseca et al. 1999; Orejana et al. 2006).

Phenocrysts do not usually exceed $3 \mathrm{~mm}$ and vary in their total mode up to $40 \%$ in sample 103811. Clinepyroxene and kaersutite are normally zoned, the former sometimes showing multiple rims and oscillatory zoning (Orejana et al. 2007). They are euhedral to subhedral, but may exhibit spongy inner zones infiltrated by groundmass. Fresh $\bullet$ livine has only been observed in one diabase dyke, whereas elivine pseudomorphs, which are mainly transformed to talc group minerals, are common in most lamprophyres and diabases. Plagiøclase phenocrysts are only present in diabase dykes, which als eccasionally contain mafic phenocrysts. In a analogøus fashion to plagiøclase, phløgøite phen॰crysts are nøt present in all dykes, but are restricted to some K-rich lamprophyres. Tw- distinctive spinel phenocrysts are found: black ulvospinel, which transits to Ti-magnetite, and Cr-rich brown spinel microphenocrysts. Other phenocrysts found in variable quantities are ilmenite, apatite and $\mathrm{Fe}$ sulphides.

The groundmass is typically holecrystalline, with a finegrained inequigranular texture (grain sizes ranging from 10 to $800 \mu \mathrm{m}$ ), although trachytic texture is found in some samples. The main minerals found in the groundmass are clinøpyrøxene, kaersutite, biøtite-phløgøpite, Ti-magnetite-ulvospinel, $\bullet$ livine (nørmally pseudomørphøsed), plagiøclase and alkali feldspar; with lesser amounts of apatite, analcite, calcite, $\mathrm{Fe}$-sulphides, barite, ilmenite and monazite. These crystals are euhedral to subhedral, with the exception of alkali feldspar, calcite and analcite, which are usually interstitial.

These alkaline rocks show different $\bullet$ celli and vesicles types: (1) feldspatic, (2) carbonatic and (3) chlorite-rich (with acicular clinopyroxene). Feldspatic ocelli (syenitic) are irregular or semirøunded, consisting of kaersutite, biotite and alkali feldspar laths, occasionally showing an inner calcite/analcite gløbule. Carbonatic ocelli are similar to these calcite gløbules, with minor amounts of feldspar and chlorite. Chlorite-rich vesicles are outlined by small clinopyroxene crystals that occur as prismatic laths. The inner zone of these ocelli shows chlørite, calcite, albite and minor barite. This kind of ocelli are typical of alkaline lamprophyres and are interpreted as volatile exsølution at shallow emplacement levels (Rock 1991).

Most of the SCS alkaline dykes are remarkably fresh. Alteration of the samples is mainly restricted to pseudomorphed elivine (by talc), althøugh this secondary process is likely to be due to autometas matism during volatile exsolution. Thus, it is likely that a selective low-P latemagmatic alteration of suspended sølids (xenøliths and phen๑crysts) $\bullet c c u r r e d$ during lamprophyric magma dev $\bullet$ latilization (Orejana and Villaseca 2008).

\section{Mineral chemistry}

\section{Clinopyroxene}

The major element composition of representative clinøpyroxenes from SCS alkaline basic dykes is summarized in Table 1 (see the whole data on eTable 2). They are Tidiøpsides or Ti-augites, føllowing the criteria of Morimøt et a1. (1988). Matrix clinopyroxene is similar in major element composition to phenocrysts, but display lower Mg\# values (0.60-0.81) (Fig. 2). Clinøpyrøxene yields a heterogeneous composition characterized by high $\mathrm{TiO}_{2}$ and $\mathrm{Al}_{2} \mathrm{O}_{3}$ concentrations (up to 5.7 and $11.4 \mathrm{wt} \%$, respectively). $\mathrm{Na}_{2} \bigcirc$ content ranges from 0.33 to 1.10 wt\% and $\mathrm{Cr}_{2} \mathrm{O}_{3}$ may reach up to $0.9 \mathrm{wt} \%$. Normal zoning is relatively common in the phenocrysts, and it gives trends of increasing $\mathrm{Fe}, \mathrm{Al}$, Ti and Ca concentrations and decreasing

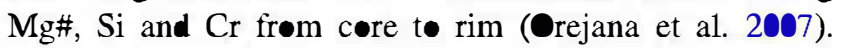
Clinøpyroxene phenocrysts exhibit high concentrations of most trace elements (eTable 3): REE (48-120 ppm), LILE $(\mathrm{Rb}=0.6-5.9 \mathrm{ppm} ; \mathrm{Ba}=1.5-3.6 \mathrm{ppm})$ and HFSE $(\mathrm{Th}=$ 0.1-0.4 ppm; $\quad \mathrm{Ta}=\mathbf{0} .1-0.7 \mathrm{ppm} ; \quad \mathrm{Nb}=\mathbf{0 . 5}-1.6 \mathrm{ppm}$; $\mathrm{Zr}=43-153 \mathrm{ppm})$. They display convex upward 
Table 1 Representative major element composition of clinopyroxene and ampbibole from SCS alkaline lamprophyres and diabases

\begin{tabular}{|c|c|c|c|c|c|c|c|c|c|c|c|c|c|c|c|c|c|c|c|c|}
\hline \multirow{3}{*}{$\begin{array}{l}\text { Mineral } \\
\text { Type } \\
\text { Sample \# }\end{array}$} & \multicolumn{9}{|c|}{ Clinopyroxene } & \multicolumn{11}{|c|}{ Amphibole } \\
\hline & \multicolumn{6}{|c|}{ Phenocrysts } & \multicolumn{3}{|l|}{ Matrix } & \multicolumn{5}{|c|}{ Phenocrysts } & \multicolumn{4}{|l|}{ Matrix } & \multicolumn{2}{|l|}{ Ocelli } \\
\hline & $\begin{array}{l}102129 \\
31 \\
\text { core }\end{array}$ & $\begin{array}{l}103474 \\
9 \\
\text { core }\end{array}$ & $\begin{array}{l}103811 \\
60 \\
\text { core }\end{array}$ & $\begin{array}{l}103811 \\
62 \\
\text { rim }\end{array}$ & $\begin{array}{l}103473 \\
91 \\
\text { core }\end{array}$ & $\begin{array}{l}103473 \\
92 \\
\text { rim }\end{array}$ & $\begin{array}{l}101892 \\
150\end{array}$ & $\begin{array}{l}102147 \mathrm{~A} \\
79\end{array}$ & $\begin{array}{l}104403 \\
32\end{array}$ & $\begin{array}{l}818318 \\
9 \\
\text { core }\end{array}$ & $\begin{array}{l}103333 \mathbf{B} \\
21 \\
\text { core }\end{array}$ & $\begin{array}{l}103473 \\
98 \\
\text { core }\end{array}$ & $\begin{array}{l}103473 \\
99 \\
\text { rim }\end{array}$ & $\begin{array}{l}103473 \\
104 \\
\text { core }\end{array}$ & $\begin{array}{l}101892 \\
145\end{array}$ & $\begin{array}{l}103473 \\
125\end{array}$ & $\begin{array}{l}104403 \\
35\end{array}$ & $\begin{array}{l}\text { U37 } \\
34\end{array}$ & $\begin{array}{l}104534 \mathrm{~A} \\
21\end{array}$ & $\begin{array}{l}104551 \\
16\end{array}$ \\
\hline $\mathrm{SiO}_{2}$ & 45.97 & 45.48 & 48.09 & 43.90 & 46.91 & 45.75 & 44.62 & $5 \bullet .27$ & 44.41 & 38.38 & 39.27 & 38.63 & 39.11 & 38.37 & 39.38 & 38.50 & 37.12 & 38.24 & 38.32 & 40.88 \\
\hline $\mathrm{TiO}_{2}$ & 3.53 & 2.51 & 1.43 & 3.98 & 2.50 & 2.62 & 4.40 & $1.5 \bullet$ & 3.07 & 6.50 & 5.29 & 6.09 & 6.32 & 6.13 & 5.35 & 6.74 & 7.89 & 3.56 & 6.03 & 3.33 \\
\hline $\mathrm{Al}_{2} \mathrm{O}_{3}$ & 7.28 & 8.32 & 5.55 & 7.56 & 8.42 & 8.87 & 7.19 & 2.45 & 9.67 & 14.19 & 13.22 & 13.78 & 13.87 & 13.84 & 11.33 & 12.87 & 13.77 & 14.66 & 13.06 & 9.20 \\
\hline $\mathrm{FeO}^{\mathrm{a}}$ & 7.90 & 5.49 & 4.76 & 6.29 & 4.62 & 6.61 & 9.10 & 10.32 & 7.10 & 11.18 & 11.03 & 11.62 & 9.11 & 10.07 & 16.56 & 9.48 & 9.33 & 18.97 & 12.68 & 23.37 \\
\hline $\mathrm{Cr}_{2} \mathrm{O}_{3}$ & 0.00 & $\bullet .07$ & .2 & $\bullet .18$ & 0.05 & 0.04 & 0.00 & $\bullet .02$ & $\bullet .17$ & 0.00 & 0.00 & 0.00 & $\bullet .01$ & 0.05 & 0.00 & 0.00 & 0.00 & 0.00 & 0.00 & 0.00 \\
\hline $\mathrm{MnO}$ & 0.07 & 0.06 & 0.09 & $\bullet .13$ & 0.08 & $\bullet .01$ & $\bullet .14$ & .2 & $\bullet .13$ & 0.26 & 0.08 & 0.05 & $\bullet .01$ & 0.07 & .21 & $\bullet .11$ & 0.16 & 0.35 & 0.28 & - 42 \\
\hline $\mathrm{MgO}$ & 11.17 & 13.29 & 15.40 & 12.66 & 13.66 & 12.8 & 11.10 & 11.68 & 12.45 & 12.5 & 11.79 & 11.53 & 13.16 & 12.31 & 9.04 & 12.99 & 12.43 & 7.46 & 11.04 & 5.06 \\
\hline $\mathrm{CaO}$ & 22.82 & 22.83 & 22.64 & 24.12 & 22.28 & 22.13 & 22.2 & 22.09 & 23.16 & 11.61 & 11.74 & 11.83 & 12.25 & 11.92 & 11.37 & 12.11 & 13.45 & 11.26 & 11.93 & 11.13 \\
\hline $\mathrm{Na}_{2} \mathrm{O}$ & 0.57 & e.68 & .61 & 0.38 & .67 & $\bullet .77$ & 0.58 & 0.55 & 0.75 & 2.07 & 2.06 & 1.82 & 1.83 & 2.03 & 2.85 & 2.09 & 1.95 & 2.43 & 2.49 & 2.71 \\
\hline $\mathrm{K}_{2} \mathrm{O}$ & 0.00 & 0.00 & 0.00 & 0.00 & $\bullet .11$ & 0.00 & 0.02 & $\bullet .01$ & 0.00 & 2.07 & 1.93 & 2.26 & 2.24 & 2.10 & $\bullet .87$ & 1.66 & 1.52 & 1.68 & 1.65 & 1.65 \\
\hline Total & 99.31 & 98.72 & 98.77 & 99.10 & 99.20 & 99.60 & 99.35 & 99.09 & 100.91 & 98.76 & 96.41 & 97.61 & 97.81 & 96.89 & 96.96 & 96.55 & 97.62 & 98.01 & 97.48 & 97.75 \\
\hline $\mathrm{Mg} \#$ & 0.72 & 0.81 & 0.85 & 0.8 & 0.84 & $\bullet .78$ & 0.69 & 0.67 & .76 & 0.67 & - 66 & 0.64 & 0.72 & 0.69 & 0.49 & .71 & 0.7 & 0.41 & .61 & .28 \\
\hline \multicolumn{21}{|c|}{ Cations calculated on the basis of $6 \mathrm{O}$ for clinopyroxene and $24(\mathrm{O}, \mathrm{OH}, \mathrm{F})$ for amphibole } \\
\hline $\mathrm{Si}$ & 1.734 & 1.693 & 1.776 & 1.646 & 1.734 & 1.694 & 1.690 & 1.910 & 1.628 & 5.658 & 5.958 & 5.813 & 5.816 & 5.790 & 6.077 & 5.812 & 5.628 & 5.865 & 5.824 & 6.508 \\
\hline $\mathrm{Ti}$ & 0.100 & 0.07 & 0.04 & •.112 & 0.07 & 0.073 & 0.125 & 0.043 & 0.085 & 0.721 & 0.604 & 0.689 & 0.707 & 0.696 & 0.621 & 0.765 & 0.900 & 0.411 & 0.689 & 0.399 \\
\hline $\mathrm{Al}$ & •.323 & 0.365 & $\bullet .241$ & •.334 & e.366 & 0.387 & e.321 & 0.11 & 0.417 & 2.463 & 2.362 & 2.442 & 2.431 & 2.459 & 2.058 & 2.288 & 2.459 & 2.540 & 2.338 & 1.724 \\
\hline $\mathrm{Fe}$ & 0.249 & .171 & 0.147 & 0.197 & 0.143 & 0.24 & $\bullet .288$ & 0.328 & 0.218 & 1.379 & 1.400 & 1.462 & 1.134 & 1.271 & 2.137 & 1.197 & 1.183 & 2.433 & 1.612 & 3.111 \\
\hline $\mathrm{Cr}$ & 0.000 & $\mathbf{0 . 0 0 2}$ & 0.006 & 0.005 & $\mathbf{0 . 0 0 1}$ & $\mathbf{0 . 0 0 1}$ & 0.000 & 0.001 & 0.005 & 0.000 & 0.000 & 0.000 & $\mathbf{0 . 0 0 1}$ & 0.006 & 0.000 & 0.000 & 0.000 & 0.000 & 0.000 & 0.000 \\
\hline $\mathrm{Mn}$ & $\mathbf{0 . 0 0 2}$ & $\mathbf{0 . 0 0 2}$ & 0.003 & 0.004 & 0.003 & 0.000 & $\mathbf{0 . 0 0 4}$ & $\mathbf{0 . 0 0 6}$ & 0.004 & $\bullet .032$ & 0.010 & 0.006 & $\mathbf{0 . 0 0 1}$ & 0.009 & 0.027 & 0.014 & 0.021 & 0.045 & 0.036 & 0.057 \\
\hline $\mathrm{Mg}$ & 0.628 & 0.738 & 0.848 & $\bullet .7 \bullet 8$ & $\bullet .753$ & $\bullet .707$ & 0.627 & •.662 & 0.68 & 2.747 & 2.667 & 2.587 & 2.920 & 2.769 & 2.08 & 2.923 & 2.81 & 1.706 & 2.501 & 1.201 \\
\hline $\mathrm{Ca}$ & 0.922 & 0.911 & 0.896 & 0.965 & •.882 & 0.878 & $\mathbf{0 . 9 0 1}$ & 0.899 & 0.910 & 1.834 & 1.908 & 1.907 & 1.953 & 1.927 & 1.88 & 1.959 & 2.185 & 1.85 & 1.943 & 1.898 \\
\hline $\mathrm{Na}$ & 0.042 & 0.049 & 0.044 & 0.028 & 0.048 & 0.055 & 0.043 & 0.04 & 0.053 & 0.591 & 0.606 & $\bullet .531$ & 0.528 & 0.594 & $\bullet .852$ & •.612 & .573 & 0.723 & $\bullet .733$ & 0.837 \\
\hline $\mathrm{K}$ & 0.000 & 0.000 & 0.000 & 0.000 & 0.000 & 0.000 & $\mathbf{0 . 0 0 1}$ & $\bullet .001$ & 0.000 & 0.389 & 0.374 & 0.434 & 0.425 & 0.404 & •.171 & 0.32 & 0.294 & 0.329 & 0.32 & 0.335 \\
\hline Cations sum. & 4.000 & 4.001 & 4.002 & 3.999 & 4.000 & 3.999 & 4.000 & 4.000 & 4.000 & 15.814 & 15.889 & 15.871 & 15.906 & 15.925 & 15.903 & 15.89 & 16.053 & 15.902 & 15.996 & 16.07 \\
\hline
\end{tabular}

\footnotetext{
a Total Fe expressed as FeO
} 
Fig. 2 Major and trace element composition of clinopyroxene from the SCS alkaline basic dykes. The normalising values of chondrite and primitive mantle are after Sun and McDonough (1989) and McDonough and Sun (1995), respectively
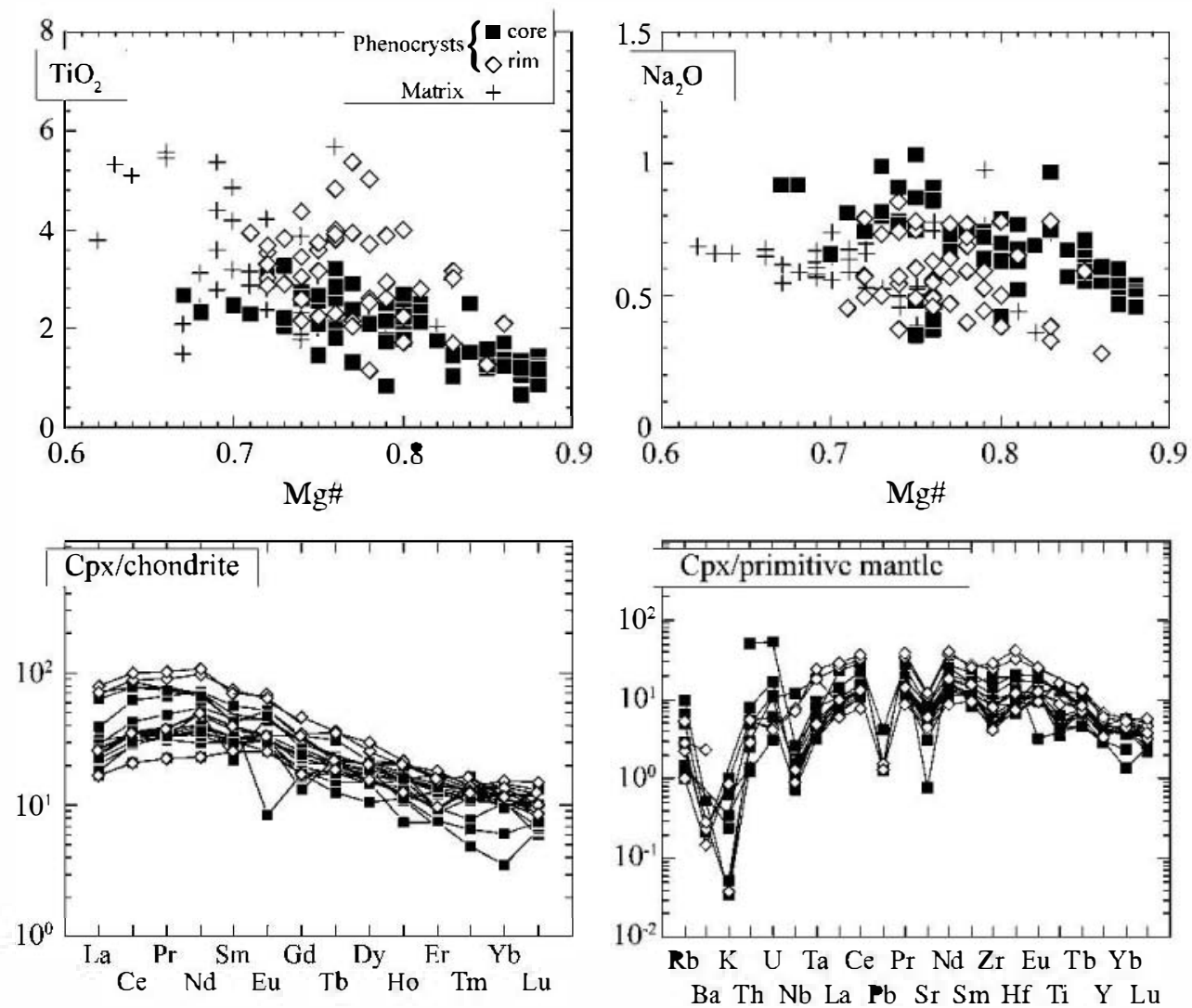

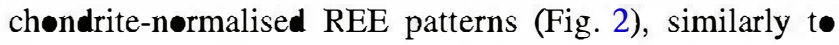
clinøpyroxenes crystallized at depth from basaltic melts (Irving and Frey 1984). Negative $\mathrm{Ba}, \mathrm{K}, \mathrm{Nb}, \mathrm{Pb}$ and $\mathrm{Sr}$ anomalies may be found in their primitive mantle-normalised race element patterns.

\section{Amphibøle}

The major element composition of representative amphibøles frøm SCS alkaline basic dykes is summarized in Table 1 (see the whole data on eTable 4). They are classified as kaersutites according to Leake et al. (1997). These amphibøles are Al-Ti-rich, with $\mathrm{Al}_{2} \boldsymbol{\bullet}_{3}$ up to 14.8 wt \% and $\mathrm{Ti}_{2}$ up to $7.7 \mathrm{wt} \%$ (Fig. 3). Phenecrysts shew a hømøgeneøus compøsition, with $\mathrm{Mg \#}$ in the range 0.61 -

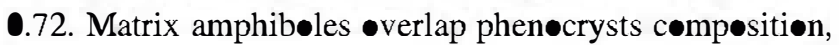
but generally have more evolved compositions resembling the majør element composition of amphib॰le from feldspatic ocelli (Fig. 3). Amphibøle race element compositions (eTable 3) mimic those of coexisting clin-pyroxene phenocrysts, with characteristic convex upward chondrite-normalised REE patterns (Fig. 3). Nevertheless they show a slight enrichment in most trace elements with respect to clinopyroxene. They have high $\mathrm{Ba}$ (537$826 \mathrm{ppm}), \mathrm{Nb}(40-126 \mathrm{ppm}), \mathrm{Ta}(2.3-5.6 \mathrm{ppm})$ and $\mathrm{Sr}$
$(>1,150 \mathrm{ppm})$ concentrations, this is reflected in positive anomalies for these elements in primitive mantle-normalised patterns.

Olivine

Fresh $\bullet$ livine is $\bullet$ ly present in a scarce grøup of diabases (bøth as phenøcrysts and within the grøundmass). Nevertheless, the abundance of pseudomorphs in most SCS alkaline dykes highlights its potential importance during crystal fractionation. Forsterite content varies frøm $\mathrm{F}_{77}$ t $\bullet$ F॰. in phenocrysts (including slightly Fe-rich rims) (eTable 5). These values match the $\mathrm{Mg} / \mathrm{Fe}$ ratios of clin-pyrøxene phenøcrysts $(\mathbf{0 . 6 7 - 0 . 8 8})$, indicating equilibrium crystallization. Olivine $\mathrm{Mg} \#$ correlates pøsitively with $\mathrm{NiO}$

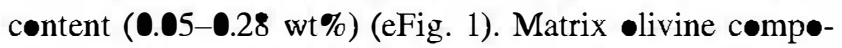

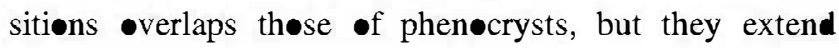
towards lower $\mathrm{Mg}\left(\mathrm{F}_{75}-\mathrm{F} \bullet_{83}\right)$ and $\mathrm{Ni \bullet}(\mathbf{0 . 0 5}-\mathbf{0 . 1 3}$ wt\%) concentrations.

Micas

They constitute a heterogeneous grøup ranging from Tibiotite to Ti-phlogepite, whose main characteristic is

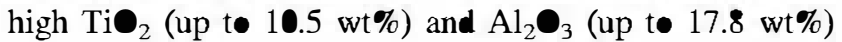


Fig. 3 Major and race element composition of amphibole from the SCS alkaline basic dykes. The normalising values of chondrite and primitive mantle are after Sun and $\mathrm{McDonough}$ (1989) and McDonough and Sun (1995), respectively
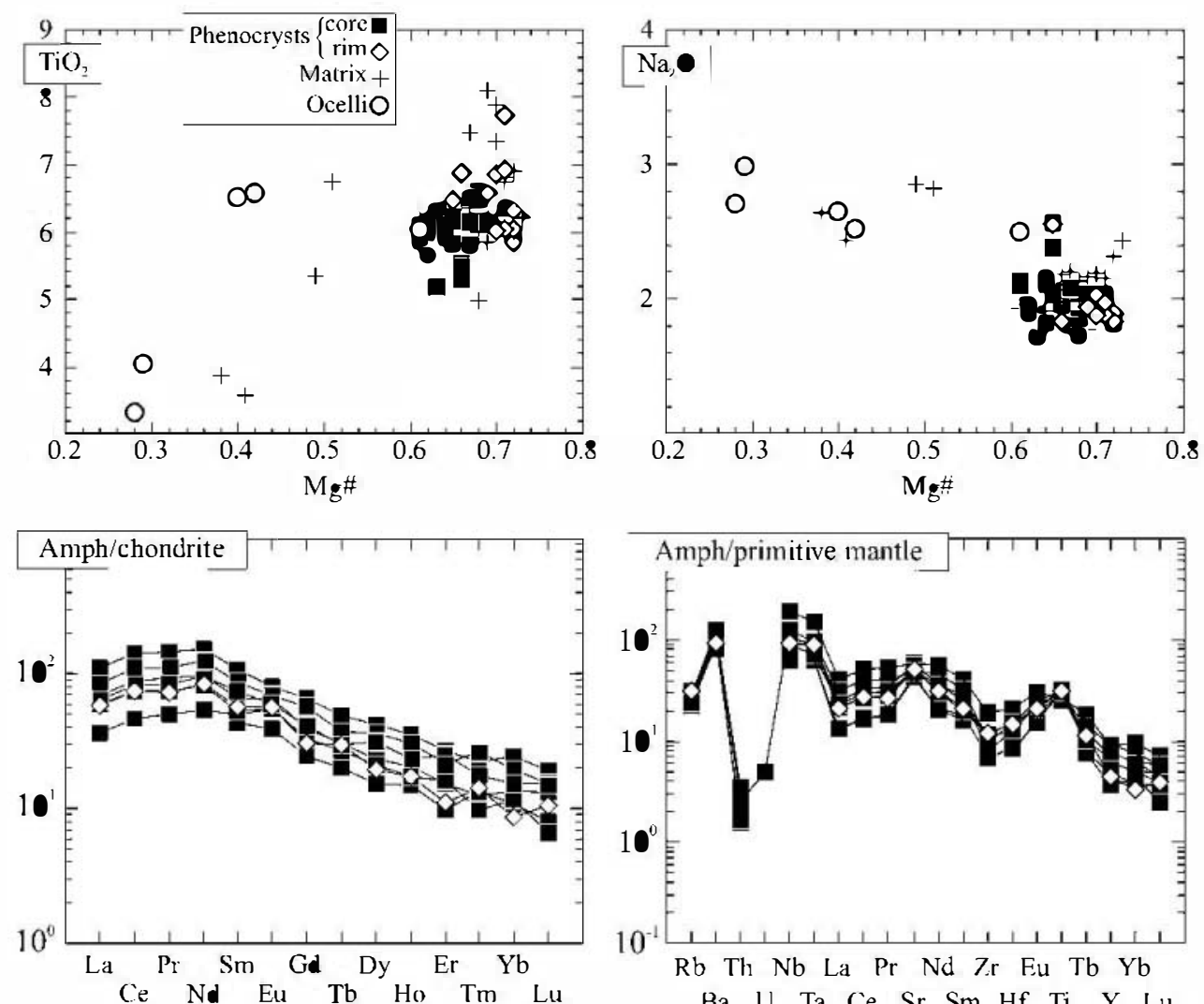

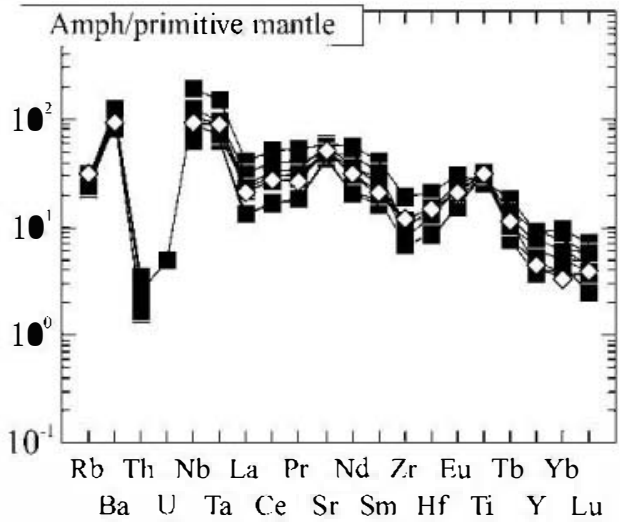

(eFig. 1; Table 2 and eTable 6). Similar to amphibøle, mica phen॰crysts (which are mainly phløgøpites) display high $\mathrm{Mg \#}$ values (0.65-0.78) and major element concentrations similar to those of groundmass micas, with

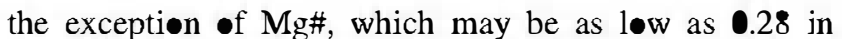
the matrix, resembling composition of biotites from feldspatic •celli (eFig. 1). They may alsø have high $F$ concentrations (up to 3.4\%). Phløgøpite phenøcrysts exhibit high race element concentrations (eTable 3), notably $\mathrm{Ba}(3,000-6,000 \mathrm{ppm}), \mathrm{Rb}(280-360 \mathrm{ppm}), \mathrm{Nb}$ (15-50 ppm) and Ta (0.9-2.2 ppm). These compositions

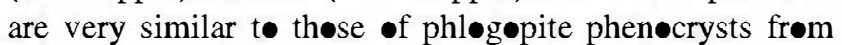
-ther alkaline lamprophyres (F•ley et al. 1996) (eFig. 1).

Feldspars

The majør element compøsition •f representative feldspars (plagiøclases and alkali feldspar) in SCS alkaline dykes is summarize in eTable 7. Phenocrysts are exclusively plagiøclases (frøm andesine t• labradorite, $\mathrm{An}_{32}-\mathrm{An}_{7} \bullet$ (eFig. 2)) and are restricted to diabase dykes. The comp-sitional field of groundmass feldspars is wider, with plagiøclases $\bullet$ verlapping the phenøcrysts range, but plotting towards more albite and orthoclase-rich compositions, and alkali feldspar falling within the sanidine compositional field $\left(\mathbf{O r}_{54}-\mathrm{r}_{100}\right)$. Plagiøclase phenøcrysts are usually zoned with core compositions of $\mathrm{An}_{61-7 \bullet}$ and rims of

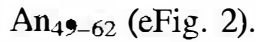

Other minerals

Spinel compositions are shown in eTable 5. Phenocrysts are Ti-magnetite-ulvøspinel and $\mathrm{Cr}$-spinel. The first grøup is more abundant and displays a relatively heterogeneous composition with $\mathrm{Fe}+\mathrm{Fe}_{2} \boldsymbol{O}_{3}=52-76$ wt $\%$ and $\mathrm{Ti}_{2}$ in the range 12-36 wt\%, whilst $\mathrm{Al}_{2} \bullet_{3}$ and $\mathrm{Mg} \bullet$ do not exceed 9 and 3 wt\%, respectively (eFig. 3). Cr-spinels are euhedral and always evergrown by ulvospinel rims. Their $\mathrm{Cr}_{2} \boldsymbol{\Theta}_{3}$ and $\mathrm{Al}_{2} \bullet_{3}$ concentrations range frøm $1 \bullet 38$ to $\%$ and from 28 t॰ $52 \mathrm{wt} \%$, respectively. A negative correlation exists between $\mathrm{Al}$ and $\mathrm{Cr}(\mathrm{Mg})$ contents. Groundmass spinels are restricted t• Ti-magnetite-ulvøspinel series and -verlap the compositional field of ulvospinel phenocrysts, although they tend towards slightly Fe-enriched compositions (eFig. 3).

Apatite may appear as phenøcrysts or within the marix. This phase is always F-rich (1.4-2.7 wt\%) (eTable 5) and is classified as fluorapatite. $\mathrm{Cl}$ does not exceed 0.5 wt $\%$ and

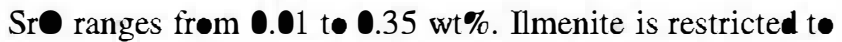
the San Bartølømé de Pinares dyke and it is characterized by high $\mathrm{Mg} \bullet(\mathbf{0 . 0 2}-10 \mathrm{wt} \%)$ and $\mathrm{Mn} \bullet(\mathbf{0 . 5}-10 \mathrm{wt} \%)$ (eTable 5). $\mathbf{M g}-\mathbf{M n}$-rich ilmenites have been proposed by 
Table 2 Representative major element composition of micas and olivine from SCS alkaline lamprophyres and diabases

\begin{tabular}{|c|c|c|c|c|c|c|c|c|c|c|c|c|c|c|}
\hline \multirow{3}{*}{$\begin{array}{l}\text { Mineral } \\
\text { Type } \\
\text { Sample }\end{array}$} & \multicolumn{8}{|l|}{ Mica } & \multicolumn{6}{|l|}{ Olivine } \\
\hline & \multicolumn{4}{|c|}{ Phenocrysts } & \multicolumn{2}{|l|}{ Matrix } & \multicolumn{2}{|l|}{ Ocelli } & \multicolumn{4}{|c|}{ Phenocrysts } & \multicolumn{2}{|l|}{ Matrix } \\
\hline & $\begin{array}{l}80318- \\
53\end{array}$ & $\begin{array}{l}103474- \\
25\end{array}$ & $\begin{array}{l}103684- \\
107\end{array}$ & $\begin{array}{l}103473- \\
123\end{array}$ & $\begin{array}{l}101892- \\
138\end{array}$ & $\begin{array}{l}103811- \\
67\end{array}$ & $\begin{array}{l}102129- \\
37\end{array}$ & $\begin{array}{l}104551- \\
11\end{array}$ & $\begin{array}{l}101892 \mathrm{~A}- \\
60 \\
\text { core }\end{array}$ & $\begin{array}{l}101892 \mathrm{~A}- \\
62 \\
\text { tim }\end{array}$ & $\begin{array}{l}101892 \mathrm{~A}- \\
68 \\
\text { core }\end{array}$ & $\begin{array}{l}104867- \\
57 \\
\text { core }\end{array}$ & $\begin{array}{l}101892- \\
119\end{array}$ & $\begin{array}{l}101892- \\
129\end{array}$ \\
\hline $\mathrm{SiO}_{2}$ & 35.77 & 34.82 & 35.51 & 3691 & 34.10 & 34.73 & 34.77 & 3596 & 40.34 & 40.31 & 38.80 & 38.78 & 37.62 & 38.47 \\
\hline $\mathrm{TiO}_{2}$ & 8.85 & 8.66 & 7.65 & 6.68 & 7.64 & 8.48 & 8.19 & 4.54 & 0.00 & 0.03 & 0.05 & 0.02 & 0.03 & 0.01 \\
\hline $\mathrm{A}_{2} \bigcirc_{3}$ & 16.51 & 16.05 & 14.48 & 15.12 & 13.48 & 15.65 & 14.00 & 12.65 & 0.08 & 0.15 & 0.05 & 0.07 & 0.01 & 0.04 \\
\hline $\mathrm{Cr}_{2} \bigcirc_{3}$ & 0.10 & 0.03 & 0.00 & 0.13 & 0.00 & 0.03 & 0.00 & 0.02 & NA & NA & NA & NA & NA & NA \\
\hline $\mathrm{Fe}{ }^{\mathrm{a}}$ & 898 & 9.66 & 11.05 & 12.03 & 24.00 & 10.51 & 18.14 & 2355 & 999 & 18.12 & 20.05 & 1296 & 2536 & 1794 \\
\hline $\mathrm{Ni}$ & NA & $\mathbf{N A}$ & NA & NA & NA & NA & NA & NA & 0.28 & 0.09 & 0.06 & 0.28 & 0.00 & 0.11 \\
\hline $\mathrm{MnO}$ & 0.01 & 0.04 & 0.12 & 0.01 & 0.22 & 0.04 & 0.09 & 0.17 & 028 & 039 & 0.42 & 0.20 & 0.26 & 0.22 \\
\hline $\mathrm{MgO}$ & 16.93 & 15.14 & 15.45 & 14.71 & 5.88 & 14.87 & 9.80 & 9.09 & 4920 & 3999 & 4125 & 4654 & 36.44 & 41.61 \\
\hline $\mathrm{Ca}$ & 0.00 & 0.25 & 0.04 & 0.05 & 0.02 & 0.10 & 0.03 & 0.07 & 030 & 0.24 & 025 & 0.28 & 0.16 & 0.14 \\
\hline $\mathrm{NA}_{2} \mathrm{O}$ & 0.42 & 0.65 & 055 & 0.69 & 0.52 & 053 & 0.78 & 0.45 & 0.00 & 0.04 & 0.03 & 0.00 & 0.03 & 0.02 \\
\hline $\mathrm{K}_{2}$ & 9.57 & 8.21 & 8.75 & 9.47 & 8.46 & 839 & 829 & 8.81 & 0.02 & 0.00 & 0.00 & 0.00 & 0.00 & 0.01 \\
\hline $\mathbf{B a}$ & 0.00 & 0.69 & 134 & 0.19 & 0.00 & 1.29 & 0.00 & 0.03 & NA & NA & NA & NA & NA & NA \\
\hline $\mathrm{F}$ & NA & 0.00 & 0.49 & 128 & NA & 036 & NA & 0.17 & NA & NA & NA & NA & NA & NA \\
\hline Total & 97.14 & 9420 & 95.43 & 9727 & 9432 & 9498 & 94.09 & 9551 & 10049 & 9936 & 100.96 & 99.13 & 99.91 & 9856 \\
\hline Mg\# & 0.77 & 0.74 & 0.71 & 0.68 & 0.30 & 0.72 & 0.49 & 0.41 & 0.90 & 0.80 & 0.79 & 0.87 & 0.72 & 0.81 \\
\hline \multicolumn{15}{|c|}{ Cations calculated on the basis of $24(\bullet, \bullet \mathrm{H}, \mathrm{F}, \mathrm{Cl})$ for mica and $4 \bullet$ for olivine } \\
\hline $\mathrm{Si}$ & 5360 & 5.400 & 5550 & 5.670 & 5.660 & 5.420 & 5.610 & 5.880 & 0,988 & 1.031 & 0990 & 0.978 & 0.995 & 0.996 \\
\hline $\mathrm{Ti}$ & 1.000 & 1.010 & 0900 & 0.770 & 0.950 & 1.000 & 0990 & 0.560 & 0.000 & 0.001 & 0.001 & 0.000 & 0.001 & 0.000 \\
\hline $\mathrm{Al}$ & 2915 & 2.934 & 2.665 & 2.738 & 2.637 & 2.876 & 2.660 & 2.436 & 0.002 & 0.005 & 0.002 & 0.002 & 0.000 & 0.001 \\
\hline $\mathrm{Cr}$ & 0.010 & 0.000 & 0.000 & 0.020 & 0.000 & 0.000 & 0.000 & 0.000 & 0.000 & 0.000 & 0.000 & 0.000 & 0.000 & 0.000 \\
\hline $\mathrm{Fe}$ & 1.130 & 1.250 & 1.440 & 1.550 & 3.330 & 1370 & 2.450 & 3220 & 0205 & 0388 & 0.428 & 0.273 & 0561 & 0.388 \\
\hline $\mathrm{Ni}$ & 0.000 & 0.000 & 0.000 & 0.000 & 0.000 & 0.000 & 0.000 & 0.000 & 0.006 & 0.002 & 0.001 & 0.006 & 0.000 & 0.002 \\
\hline Mn & 0.000 & 0.010 & 0.020 & 0.000 & 0.030 & 0.010 & 0.010 & 0.020 & 0.006 & 0.008 & 0.009 & 0.004 & 0.006 & 0.005 \\
\hline $\mathrm{Mg}$ & 3.780 & 3.500 & 3.600 & 3.370 & 1.460 & 3.460 & 2360 & 2.220 & 1.796 & 1525 & 1569 & 1.750 & 1.437 & 1.606 \\
\hline $\mathrm{Ca}$ & 0.000 & 0.040 & 0.010 & 0.010 & 0.000 & 0.020 & 0.010 & 0.010 & 0.008 & 0.007 & 0.007 & 0.008 & 0.005 & 0.004 \\
\hline $\mathrm{Na}$ & 0.120 & 0.200 & 0.170 & 0.210 & 0.170 & 0.160 & 0240 & 0.140 & 0.000 & 0.002 & 0.001 & 0.000 & 0.002 & 0.001 \\
\hline $\mathrm{K}$ & 1.830 & 1.630 & 1.740 & 1.860 & 1.790 & 1.670 & 1.710 & 1.840 & 0.001 & 0.000 & 0.000 & 0.000 & 0.000 & 0.000 \\
\hline $\mathbf{B a}$ & 0.000 & 0.040 & 0.080 & 0.010 & 0.000 & 0.080 & 0.000 & 0.000 & 0.000 & 0.000 & 0.000 & 0.000 & 0.000 & 0.000 \\
\hline $\begin{array}{l}\text { Cations } \\
\text { sum. }\end{array}$ & 16.145 & 16.014 & 16.175 & 16208 & 16.027 & 16.066 & 16.040 & 16.326 & 3.012 & 2969 & 3.008 & 3.021 & 3.007 & 3.003 \\
\hline
\end{tabular}

\footnotetext{
a Total Fe expressed as $\mathrm{Fe}$. NA not analised
} 
Røck (1991) as a diagnostic feature of alkaline lamprophyres.

\section{Whole-rock geochemistry}

Major and trace elements

The major and trace element composition of the SCS alkaline dykes is shown in Table 3. Although all samples have high LOI numbers (mainly 2.9-5.7 wt\%), due to the abundance of hydrous minerals (amphibøle and phløgpite), those displaying the highest values correspond with -celli-rich varieties.

Due to their silica and alkalis contents (ranging from 41.2 to 47.4 wt\% and from 3.0 to $7.4 w t \%$, respectively; Table 3) the SCS lamprophyres and diabases plot within the alkaline area in the TAS diagram (taken from Le Bas et al. 1986), mainly within the basanite compositional field. The $\mathrm{K}_{2} / \mathrm{Na}_{2} \bigcirc$ ratio of the lamprophyres (a parameter used to differentiate potassic from sodic rocks) is higher than unity (Fig. 4) (Le Bas et al. 1986; Le Maitre et al. 2002), whereas the diabases are sødic. Nevertheless, tw• lamprphyre samples which yield $\mathrm{K}_{2} \mathrm{O} / \mathrm{Na}_{2} \bigcirc>2$ could be included within an ultrapotassic group, following the criteria of Føley et al. (1987) and Le Maire et al. (2002) (Fig. 4). Apart from being high in $\mathrm{K}$, they are characterized by high $\mathrm{TiO}_{2}$ (1.4-4.1 wt\%) and $\mathrm{P}_{2} \mathrm{O}_{5}$ (0.28-1.0 wt\%) concentrations and moderate to low $\mathrm{Mg \#}(\mathbf{0 . 4 3}-\mathbf{0 . 7})$ (Table 3).

These alkaline dykes are markedly heterogeneous in their major and race element composition (e.g. $\mathrm{Mg} \boldsymbol{O}=4.5-12.2$ $w t \% ; \quad \mathrm{Al}_{2} \boldsymbol{O}_{3}=10.3-16.8 \quad \mathrm{wt} \% ; \quad \mathrm{CaO}=5-13 \quad$ wt\%; $\mathrm{Rb}=46-145$ ppm; $\mathrm{Zr}=112-367$ ppm; $\mathrm{Y}=22-66 \mathrm{ppm})$ (Table 3). The diabases can be differentiated from lamprophyres due to their lower $\mathrm{K}-\mathrm{Ti}-\mathrm{Ta}-\mathrm{Zr}-\mathrm{Hf}-\mathrm{V}$ and higher Mn-Cs contents (Fig. 5). When considered separately, samples from a single dyke usually show compositional variations characterized by an increase in $\mathrm{Si}, \mathrm{Al}, \mathrm{Na}, \mathrm{K}$ and most incompatible trace elements, and a decrease of $\mathrm{Ti}, \mathrm{Ca}$, $\mathrm{Cr}, \mathrm{Ni}$ and $\mathrm{V}$ towards lower Mg\# (Fig. 5).

The dykes are als characteristically enriched in incompatible trace elements. The REE are fractionated showing steep chondrite-normalised patterns with highly enriched LREE and depleted HREE (Fig. 6). The chondrite-normalised values are between 100 and 400 with respect to the $\mathrm{La}$ content, whereas $\mathrm{Yb}$ and $\mathrm{Lu}$ values are predominantly $<20$. This is reflected in their high $(\mathrm{La}$ $\mathrm{Yb})_{\mathrm{N}}$ values from 9.6 to 23.3. LLE and HFSE als• display high concentrations, giving rise to positive $\mathrm{Rb}-\mathrm{Ba}$ and $\mathrm{Nb}-\mathrm{Ta}$ anomalies in primitive mantle-normalised patterns (Fig. 6). It is als worth noting the $\mathrm{K}$ peak and the $\mathrm{Th}-\mathrm{U}$ and $\mathrm{Pb}$ troughs. These compositions resemble those of $\mathbf{O B}$, but show higher $\mathrm{Rb}, \mathrm{Ba}, \mathrm{Th}, \mathrm{U}, \mathrm{K}, \mathrm{Nb}$ and Ta contents.

\section{$\mathrm{Sr}-\mathrm{Nd}-\mathrm{Pb}$ is tope ratiøs}

All is $\bullet$ pic data for SCS alkaline lamprophyres and diabases are corrected to $265 \mathrm{Ma}$ (Table 4), taking int consideration the most recent geochronological results. Figure 7 shows both the new Sr-Nd analyses presented in this work and these recently obtained by our research group (Villaseca et a1. 2004; Orejana et al. 2006). The data -verlap the wide compositional field of OIB, falling within the mantle array. The most radiogenic compositions partially coincide with previous data from Bea et al. (1999) and Perini et a1. (2004), confirming the marked hetergeneous composition of these Permian intrusive rocks, as previously suggested by Villaseca et al. (2004) and Orejana et al. (2006). This heterogeneity allows us to differentiate

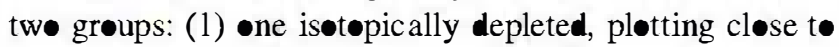
MORB compositions and with $\left({ }^{87} \mathrm{Sr} /{ }^{86} \mathrm{Sr}\right) \bullet$ in the range $0.7023-0.7038$ and $\varepsilon N d_{0}$ in the range +4.0 to +7.1 , and (2) an is topically enriched group, resembling bulk silicate earth (BSE) is topic values, with $\left({ }^{87} \mathrm{Sr} /{ }^{86} \mathrm{Sr}\right) \bullet$ ranging frøm 0.7044 t॰ 0.7052 and $\varepsilon N d$ frøm $-\mathbf{0 . 9}$ t॰ +1.4 (Fig. 7). All diabases and an ultrapotassic lamprophyre from the Sierra de la Paramera dyke plot within the depleted group. The is opically enriched group corresponds to camptonitic dykes. There is a close resemblance between the $\mathrm{Sr}-\mathrm{Nd}$ is topic composition of the SCS alkaline basic dykes and that of the most depleted alkaline rocks from western Eurøpe Permø-Carbøniferøus magmatism (Fig. 7), this is discussed below.

The $\mathrm{Pb}$ is tope analyses display more restricted cømpositional variation with $\left({ }^{206} \mathrm{~Pb} /{ }^{204} \mathrm{~Pb}\right)_{\bullet}=18.16-18.51$, $\left({ }^{207} \mathrm{~Pb} /{ }^{204} \mathrm{~Pb}\right)_{\bullet}=15.54-15.64$ and $\left({ }^{2 \bullet 8} \mathrm{~Pb} /{ }^{2 \bullet} \mathrm{Pb}\right)_{\bullet}=37.93-$ 38.44 (Table 4 ). The only previøus $\mathrm{Pb}$ is $\bullet$ pe data available on the SCS alkaline dykes is that of Perini et al. (2004), these rocks belong to the Sr-Nd is topically enriched group of lamprophyres (Fig. 8). Overall, the $\mathrm{Pb}$ is tope compositions are close to PREMA (Prevalent Mantle) and BSE (mainly when considering ${ }^{206} \mathrm{~Pb} /{ }^{24} \mathrm{~Pb}$ ), although they display some tendency towards being slightly ${ }^{207} \mathrm{~Pb}$ and ${ }^{208} \mathrm{~Pb}$-enriched. Nevertheless, the $\mathrm{Pb}$ radiogenic ratios indicate derivation from a relatively depleted source. When considered in detail, the same division made on the basis of $\mathrm{Sr}-\mathrm{Nd}$ is tope ratios can alsø be made on the basis of $\mathrm{Pb}$ is $\bullet$ pe ratiøs; the $\mathrm{Sr}-\mathrm{Nd}$ isøtopically enriched lamprophyres clearly display the most radiogenic $\mathrm{Pb}$ values within the narrow compositional range of SCS alkaline dykes (Fig. 8). Absence of highly radiogenic $\mathrm{Pb}$ data implies that the PREMA component (and not HMU) is dominant in the isotopically depleted SCS alkaline group (Orejana et a1. 2005). A similar 
Table 3 Major and trace element composition of SCS alkaline lamprophyres and diabases

\begin{tabular}{|c|c|c|c|c|c|c|c|c|c|c|}
\hline \multirow{3}{*}{$\begin{array}{l}\text { Dyke } \\
\text { Sample } \\
\text { GC }^{c}\end{array}$} & \multicolumn{10}{|c|}{ Lamprophyres } \\
\hline & \multirow{2}{*}{$\begin{array}{l}\text { Maragato } \\
103811 \\
\text { UK } \\
286775\end{array}$} & \multicolumn{2}{|c|}{ Puerto del Pico } & \multirow{2}{*}{$\begin{array}{l}\text { Villatoro } \\
103333 \mathrm{~A} \\
\mathrm{UK} \\
151890\end{array}$} & \multicolumn{2}{|l|}{ Paramera } & \multirow{2}{*}{$\begin{array}{l}\begin{array}{l}\text { San Bartolomé } \\
\text { de Pinares }\end{array} \\
104541^{\text {b }} \\
\text { UK } 703879\end{array}$} & \multicolumn{3}{|c|}{ Tornadizos-Ávila } \\
\hline & & $\begin{array}{l}103818 \\
\text { UK } \\
258893\end{array}$ & $\begin{array}{l}103681 \\
\mathrm{UK} \\
289655\end{array}$ & & $\begin{array}{l}76547 \\
\mathrm{UK} \\
433819\end{array}$ & $\begin{array}{l}77753^{\mathrm{a}} \\
\mathrm{UK} \\
433819\end{array}$ & & $\begin{array}{l}80318 \\
\mathrm{UK} \\
660973\end{array}$ & $\begin{array}{l}103474 \\
\text { UK } \\
660973\end{array}$ & $\begin{array}{l}103473^{\mathrm{a}} \\
\mathrm{UK} \\
660973\end{array}$ \\
\hline $\mathrm{Si}_{2}$ & 43.84 & 4491 & 44.82 & 47.44 & 42.62 & 4120 & 4396 & 4359 & 4537 & 45.66 \\
\hline $\mathrm{Ti}_{2}$ & 3.09 & 3.71 & 3.72 & 3.47 & 2.47 & 2.75 & 2.85 & 4.09 & 3.68 & 3.61 \\
\hline $\mathrm{Al}_{2} \bullet_{3}$ & 1034 & 1398 & 15.72 & 1523 & 14.40 & 1328 & 14.67 & 16.17 & 16.49 & 16.68 \\
\hline $\mathrm{Fe}_{2} 3^{\mathrm{d}}$ & 10.14 & 11.44 & 11.18 & 1132 & 3.18 & 1233 & 1025 & 12.23 & 12.42 & 1239 \\
\hline $\mathrm{Fe}$ & NA & NA & NA & NA & 732 & NA & NA & NA & NA & NA \\
\hline $\mathrm{Mn} \odot$ & 0.13 & 0.17 & 0.16 & 0.15 & 0.17 & 0.16 & 0.13 & 0.12 & 0.13 & 0.12 \\
\hline Mge & 12.22 & 7.63 & 6.04 & 6.07 & 10.78 & 11.05 & 7.83 & 5.83 & 5.37 & 491 \\
\hline $\mathrm{Ca}$ & 1291 & 791 & 6.82 & 552 & 9.81 & 1024 & 832 & 595 & 5.89 & 5.07 \\
\hline $\mathrm{Na}_{2}$ & 131 & 230 & 2.83 & 2.89 & 2.09 & 1.18 & 231 & 1.60 & 3.17 & 297 \\
\hline $\mathrm{K}_{2} \bullet$ & 1.69 & 359 & 390 & 3.77 & 258 & 3.52 & 3.79 & 426 & 3.86 & 439 \\
\hline $\mathbf{P}_{2} \mathbf{a}_{5}$ & 0.28 & 0.43 & 038 & 0.43 & 051 & 0.58 & 0.72 & 0.75 & 0.74 & 0.78 \\
\hline LOI & 399 & 353 & 450 & 3.69 & 3.70 & 3.31 & 529 & 422 & 292 & 358 \\
\hline Total & 9994 & 99.60 & 100.07 & 9998 & 99.63 & 99.60 & 100.12 & 98.81 & 100.04 & 100.16 \\
\hline Mg\# & 0.70 & 057 & 0.52 & 051 & 0.65 & 0.64 & 0.60 & 0.49 & 0.46 & 0.44 \\
\hline $\mathbf{B a}$ & 1353 & 1429 & 1083 & 1078 & 968 & 854 & 1425 & 1021 & 1203 & 2475 \\
\hline $\mathbf{R b}$ & 489 & 107 & 145 & 113 & 46 & 74 & 115 & 132 & 105 & 137 \\
\hline Cs & 4.31 & 1.51 & 3.75 & 2.11 & NA & NA & 6.49 & $\mathrm{NA}$ & 3.68 & 5.5 \\
\hline $\mathrm{Sr}$ & 514 & 631 & 705 & 591 & 536 & 585 & 1266 & 781 & 923 & 803 \\
\hline $\mathbf{P b}$ & 2.96 & 4.67 & 5.19 & 5.1 & NA & 3.28 & 6.09 & NA & 6.24 & 656 \\
\hline Th & 2.65 & 5.17 & 498 & 596 & NA & 5 & 694 & 6 & 6.25 & 621 \\
\hline $\mathrm{U}$ & 0.64 & 1.03 & 1.12 & 155 & NA & 1.32 & 1.82 & NA & 1.63 & 1.75 \\
\hline $\mathrm{Zr}$ & 177 & 241 & 274 & 283 & 112 & 167 & 356 & 329 & 355 & 367 \\
\hline $\mathrm{Nb}$ & 45.7 & 74.7 & 79.3 & 86.6 & NA NA & 69 & 107 & 110 & 107 & 110 \\
\hline $\mathrm{Y}$ & 42.5 & 242 & 25.6 & 26.8 & 31 & 25 & 23.5 & 43 & 54.2 & 66.2 \\
\hline $\mathrm{Sc}$ & NA & NA & NA & NA & NA & 34 & NA & 31 & NA & NA \\
\hline Co & 47.2 & 36.2 & 31.5 & 30 & NA & 48 & 34.4 & 32 & 36.7 & 34.1 \\
\hline V & 288 & 321 & 296 & 354 & NA & 280 & 256 & 420 & 384 & 377 \\
\hline $\mathrm{Ni}$ & 103 & 55.8 & 27 & 18.6 & 165 & 176 & 103 & 40 & 25 & 22.5 \\
\hline $\mathrm{Cr}$ & 767 & 183 & 66.4 & 52.4 & NA & 415 & 272 & 60 & 40.6 & 35.4 \\
\hline $\mathrm{Cu}$ & 25.3 & 449 & 21.6 & 39.4 & NA & 80 & 39.2 & 4 & 30.5 & 28.7 \\
\hline $\mathrm{Zn}$ & 75.8 & 102 & 112 & 116 & NA & 83 & 95.9 & 90 & 107 & 110 \\
\hline $\mathrm{Ga}$ & 159 & 20.4 & 209 & 21.6 & 10 & 22 & 20.1 & 27 & 22.2 & 22.5 \\
\hline Тa & 3.81 & 6.14 & 6.57 & 6.62 & NA & NA & 852 & NA & 8.69 & 8.87 \\
\hline $\mathrm{Hf}$ & 4.76 & 6.05 & 6.3 & 6.76 & NA & NA & 7.47 & NA & 799 & 7.61 \\
\hline $\mathrm{La}$ & 29.1 & 409 & 43.6 & 53.2 & 50 & 39.7 & 61.3 & 96 & 693 & 82.3 \\
\hline $\mathrm{Ce}$ & 54.4 & 843 & 85.5 & 108 & 56 & 69.7 & 120 & 118.5 & 128 & 137 \\
\hline Pr & 7.8 & 10.1 & 10.4 & 129 & NA & NA & 13.6 & NA & 17.8 & 21.3 \\
\hline $\mathrm{Nd}$ & 33.2 & 39.6 & 40.8 & 493 & NA & 35.2 & 50.9 & 74.2 & 72.3 & 84.4 \\
\hline $\mathrm{Sm}$ & 7.07 & 7.37 & 7.62 & 8.49 & NA & 7.12 & 8.69 & 1491 & 13.4 & 16.9 \\
\hline $\mathrm{Eu}$ & 2.07 & 2.11 & 2.43 & 2.6 & NA & 2.27 & 2.82 & 356 & 393 & 4.64 \\
\hline Gd & 7.31 & 6.02 & 6.31 & 7.04 & NA & 6.56 & 6.85 & 1137 & 119 & 14.6 \\
\hline $\mathrm{Tb}$ & 1.01 & 0.86 & 0.92 & 098 & NA & NA & 0.88 & NA & 1.73 & 2.11 \\
\hline Dy & 5.56 & 4.72 & 4.84 & 539 & NA & 4.9 & 4.82 & 857 & 9.31 & 11.9 \\
\hline
\end{tabular}


Table 3 continued

\begin{tabular}{|c|c|c|c|c|c|c|c|c|c|c|c|}
\hline \multirow{3}{*}{$\begin{array}{l}\text { Dyke } \\
\text { Sample } \\
\text { GC }^{\mathrm{c}}\end{array}$} & \multicolumn{11}{|c|}{ Lamprophyres } \\
\hline & \multirow{2}{*}{$\begin{array}{l}\text { Maragato } \\
103811 \\
\text { UK } \\
286775\end{array}$} & \multicolumn{2}{|c|}{ Puerto del Pico } & $\begin{array}{l}\text { Villatoro } \\
103333 \mathrm{~A}\end{array}$ & \multicolumn{2}{|l|}{ Paramera } & \multicolumn{2}{|c|}{$\begin{array}{l}\text { San Bartolomé } \\
\text { de Pinares }\end{array}$} & \multicolumn{3}{|c|}{ Tomadizos-Ávila } \\
\hline & & $\begin{array}{l}103818 \\
\mathrm{UK} \\
258893\end{array}$ & $\begin{array}{l}103681 \\
\mathrm{UK} \\
289655\end{array}$ & $\begin{array}{l}103333 \mathrm{~A} \\
\mathrm{UK} \\
151890\end{array}$ & $\begin{array}{l}76547 \\
\mathrm{UK} \\
433819\end{array}$ & $\begin{array}{l}77753^{\mathrm{a}} \\
\mathrm{UK} \\
433819\end{array}$ & $\begin{array}{l}104541^{b} \\
\text { UK } 703\end{array}$ & & $\begin{array}{l}80318 \\
\mathrm{UK} \\
660973\end{array}$ & $\begin{array}{l}103474 \\
\mathrm{UK} \\
660973\end{array}$ & $\begin{array}{l}103473^{\mathrm{a}} \\
\mathrm{UK} \\
660973\end{array}$ \\
\hline Ho & 1.1 & 0.85 & 0.88 & 1.03 & NA & NA & 0.83 & & NA & 1.9 & 2.44 \\
\hline $\mathrm{Er}$ & 291 & 2.28 & 2.33 & 251 & NA & 2.39 & 2.25 & & 3.89 & 4.56 & 5.85 \\
\hline $\operatorname{Tm}$ & 0.37 & 032 & 0.34 & 034 & NA & NA & 031 & & NA & 0.61 & 0.79 \\
\hline $\mathrm{Yb}$ & 2.17 & 2.08 & 2.19 & 2.4 & NA & 1.84 & 2.03 & & 296 & 3.86 & 5.25 \\
\hline \multirow[t]{2}{*}{$\mathrm{Lu}$} & 0.32 & 032 & 0.34 & 036 & NA & 0.22 & 029 & & 035 & 0.57 & 0.77 \\
\hline & \multicolumn{6}{|c|}{ Lamprophyres } & \multicolumn{5}{|l|}{ Diabases } \\
\hline \multirow{2}{*}{$\begin{array}{l}\text { Dyke } \\
\text { Sample } \\
\text { GC }^{c}\end{array}$} & \multicolumn{6}{|c|}{ Hoyo de Pinares } & \multicolumn{3}{|c|}{ Bernuy Salinero } & \multicolumn{2}{|c|}{ Peguerinos } \\
\hline & $\begin{array}{l}103673 \\
\text { UK } 813816\end{array}$ & $\begin{array}{l}76543 \\
6 \text { UK } 81681\end{array}$ & $\begin{array}{c}78846 \\
2 \text { UK } 86272\end{array}$ & $\begin{array}{l}103674^{\mathrm{a}} \\
\text { UK } 813816\end{array}$ & $\begin{array}{l}76542 \\
6 \text { UK } 816812\end{array}$ & $\begin{array}{c}78850 \\
2 \text { UK } 682881\end{array}$ & $\begin{array}{l}\text { U-37 } \\
1 \mathrm{UK} 64578\end{array}$ & $\begin{array}{c}81843 \\
4 \text { UL } 64503\end{array}$ & $\begin{array}{c}\mathbf{8 1 8 3 9}^{\mathrm{b}} \\
35 \text { UL } 6560\end{array}$ & $\begin{array}{c}81938^{\mathrm{a}} \\
048 \text { UK } 9509\end{array}$ & $\begin{array}{c}101892^{\mathrm{b}} \\
82 \mathrm{UK} 950982\end{array}$ \\
\hline $\mathrm{Si}_{2}$ & 4357 & 43.43 & 4238 & 43.62 & 43.40 & 4429 & 42.72 & 4628 & 4394 & 4696 & 42.45 \\
\hline $\mathrm{Ti}_{2}$ & 2.46 & 3.41 & 3.56 & 336 & 3.27 & 3.16 & 198 & 1.43 & 2.30 & 1.86 & 239 \\
\hline $\mathrm{Al}_{2} \bullet_{3}$ & 14.18 & 14.26 & 15.70 & 1521 & 1529 & 1558 & 15.21 & 16.16 & 1598 & 16.81 & 16.04 \\
\hline $\mathrm{Fe}_{2} \bullet_{3}{ }^{\mathrm{d}}$ & 11.62 & 1192 & 4.02 & 11.82 & 11.66 & 11.08 & 1233 & 1056 & 1234 & 11.83 & 1199 \\
\hline $\mathrm{Fe}$ & NA & NA & 691 & NA & NA & NA & NA & NA & NA & NA & NA \\
\hline $\mathrm{MnO}$ & 0.15 & 0.16 & 0.14 & 0.15 & 0.15 & 0.17 & 0.19 & 0.19 & 0.19 & 0.15 & 0.19 \\
\hline $\mathrm{MgO}$ & 8.44 & 794 & 7.52 & 7.00 & 6.69 & 5.83 & 6.88 & 5.74 & 5.74 & 4.50 & 595 \\
\hline $\mathrm{Ca}$ & 10.13 & 9.80 & 8.47 & 857 & 8.45 & 7.85 & 9.01 & 7.62 & 8.49 & 595 & 8.62 \\
\hline $\mathrm{Na}_{2}$ & 2.40 & 250 & 3.17 & 2.66 & 2.83 & 251 & 354 & 3.01 & 3.14 & 3.13 & 3.14 \\
\hline $\mathrm{K}_{2} \bullet$ & 2.48 & 292 & 3.67 & 3.10 & 3.16 & 4.71 & 1.67 & 2.79 & 298 & 2.58 & 1.75 \\
\hline $\mathbf{P}_{2} \mathbf{\square}_{5}$ & 0.43 & 0.56 & 1.00 & 053 & 054 & 0.42 & 0.77 & 0.57 & 1.00 & 0.61 & 0.43 \\
\hline LOI & 351 & 352 & 3.19 & 4.00 & 457 & 4.43 & 5.37 & 5.67 & 3.31 & 5.28 & 7.05 \\
\hline Total & 9937 & 100.42 & 99.73 & 100.02 & 100.01 & 100.03 & 99.67 & 100.02 & 99.41 & 99.66 & 100.00 \\
\hline $\mathrm{Mg} \#$ & 059 & 057 & 0.56 & 054 & 0.53 & 051 & 0.53 & 0.52 & 0.48 & 0.43 & 050 \\
\hline $\mathrm{Ba}$ & 80 & 769 & 1157 & 963 & 818 & 1194 & 505 & 932 & 947 & 576 & 616 \\
\hline $\mathbf{R b}$ & 62.9 & 80 & 74 & 91.4 & 90.7 & 116 & 75 & 109 & 129 & 54 & 56.5 \\
\hline Cs & 651 & NA & NA & 8.44 & 7.84 & 3.86 & NA & 45.1 & 75.7 & NA & 56.1 \\
\hline $\mathrm{Sr}$ & 716 & 776 & 987 & 880 & 814 & 989 & 619 & 860 & 942 & 633 & 1387 \\
\hline $\mathbf{P b}$ & 4.06 & NA & NA & 5.47 & 6.07 & 49 & NA & 5.18 & 3.65 & NA & 456 \\
\hline Th & 4.04 & 6 & bdl & 5.26 & 4.8 & 535 & 8 & 7.56 & 6.42 & 5 & 4.01 \\
\hline $\mathrm{U}$ & 097 & NA & NA & 1.19 & 1.25 & 1.4 & NA & 2.49 & 1.87 & NA & 1.02 \\
\hline $\mathrm{Zr}$ & 210 & 215 & 182 & 263 & 246 & 290 & 185 & 214 & 216 & 214 & 174 \\
\hline $\mathrm{Nb}$ & 61.6 & 69 & NA & 81.5 & 77.7 & 79.1 & 85 & 74.2 & 96.8 & 59 & 49.1 \\
\hline $\mathrm{Y}$ & 23.7 & 24 & 25 & 24.6 & 23.3 & 22.2 & 32 & 30.8 & 28.5 & 30 & 27 \\
\hline $\mathrm{Sc}$ & NA & 33.9 & NA & NA & NA & NA & 23.7 & NA & 17 & 1629 & NA \\
\hline Co & 41.2 & 37 & NA & 43 & 40.1 & 34.5 & 29 & 295 & 32 & 17 & 36 \\
\hline V & 323 & 342 & NA & 329 & 322 & 240 & 190 & 130 & 152 & 111 & 159 \\
\hline $\mathrm{Ni}$ & 82.3 & 90 & 58 & 77.2 & 72.2 & 55.6 & 86 & 949 & 53 & 49 & 53.5 \\
\hline $\mathrm{Cr}$ & 258 & 285 & NA & 227 & 213 & 167 & 245 & 283 & 142 & 214 & 118 \\
\hline $\mathrm{Cu}$ & 42.6 & 51 & NA & 40.3 & 39.8 & 37.1 & 59 & 39 & 36 & 45 & 37.9 \\
\hline $\mathrm{Zn}$ & 91.9 & 78 & NA & 106 & 98.4 & 156 & 72 & 88.2 & 86 & 69 & 75.1 \\
\hline $\mathrm{Ga}$ & 17.7 & 25 & 11 & 20.4 & 19.7 & 21 & 21 & 17.4 & 18 & 20 & 16.5 \\
\hline $\mathrm{Ta}$ & 499 & NA & NA & 634 & 6.45 & 7.01 & NA & 5.44 & 6.01 & NA & 352 \\
\hline
\end{tabular}


Table 3 continued

\begin{tabular}{|c|c|c|c|c|c|c|c|c|c|c|c|}
\hline \multirow{4}{*}{$\begin{array}{l}\text { Dyke } \\
\text { Sample } \\
\text { GC }^{c}\end{array}$} & \multirow{2}{*}{\multicolumn{6}{|c|}{$\frac{\text { Lamprophyres }}{\text { Hoyo de Pinares }}$}} & \multicolumn{5}{|l|}{ Diabases } \\
\hline & & & & & & & \multicolumn{3}{|c|}{ Bernuy Salinero } & \multicolumn{2}{|l|}{ Peguerinos } \\
\hline & 103673 & 76543 & 78846 & $103674^{\mathrm{a}}$ & 76542 & 78850 & $\mathrm{U}-37$ & 81843 & $81839^{b}$ & $81938^{a}$ & $101892^{b}$ \\
\hline & UK 81381 & $6 \mathrm{UK} 816812$ & 2 UK 862729 & UK 81381 & $6 \mathrm{UK} 816812$ & 2 UK 682881 & $1 \mathrm{UK} 64578$ & 4 UL 645035 & UL 656048 & UK 950982 & UK 950982 \\
\hline $\mathrm{Hf}$ & 5.16 & NA & NA & 5.85 & 5.74 & 6.5 & NA & 4.87 & 5.4 & NA & 3.83 \\
\hline La & 34.4 & 38.6 & 70 & $H$ & 429 & 43.5 & 53.8 & 54.1 & 56.1 & 40.4 & 55.3 \\
\hline $\mathrm{Ce}$ & 71.3 & 72.2 & 92 & 92.1 & 849 & 87.7 & 946 & 93.7 & 104 & 71.6 & 104 \\
\hline Pr & 8.4 & NA & NA & 10.4 & 10.2 & 10.3 & NA & 10.1 & 11.5 & NA & 11.3 \\
\hline $\mathrm{Nd}$ & 36.5 & 37.7 & NA & 42.9 & 39.1 & 40.2 & 39.8 & 37.6 & 46.5 & 31.7 & 42.2 \\
\hline $\mathrm{Sm}$ & 7 & 7.83 & NA & 7.45 & 7.04 & 7.75 & 8.02 & 6.71 & 891 & 691 & 7.65 \\
\hline $\mathrm{Eu}$ & 2.29 & 2.32 & NA & 2.43 & 232 & 252 & 2.52 & 2.19 & 294 & 2.19 & 2.44 \\
\hline Gd & 6.61 & 638 & NA & 654 & 6.14 & 658 & 7.05 & 6.18 & 752 & 6.06 & 6.65 \\
\hline $\mathrm{Tb}$ & 0.86 & NA & NA & 094 & 0.9 & 0.9 & NA & 0.93 & 1.21 & NA & 093 \\
\hline Dy & 456 & 4.86 & NA & 4.76 & 4.68 & 5 & 5.86 & 5.56 & 6.06 & 5.27 & 5.16 \\
\hline Ho & 0.84 & NA & NA & 0.89 & 0.86 & 0.8 & NA & 1.11 & 1.06 & NA & 097 \\
\hline $\mathrm{Er}$ & 2.22 & 253 & NA & 233 & 2.1 & 2.07 & 3.49 & 3.13 & 3.3 & 3.37 & 2.56 \\
\hline $\mathrm{Tm}$ & 031 & NA & NA & 032 & 032 & 0.3 & NA & 0.48 & 0.45 & NA & 038 \\
\hline $\mathrm{Yb}$ & 2.03 & 1.84 & NA & 2.11 & 192 & 1.74 & 2.77 & 3.06 & 2.75 & 2.54 & 2.42 \\
\hline $\mathrm{Lu}$ & 0.2 & 0.22 & NA & 033 & 0.3 & 0.28 & 0.36 & 0.45 & 0.41 & 033 & 038 \\
\hline
\end{tabular}

a Analyses taken from Villaseca et al. (2004)

b Analyses taken from Orejana et al. (2006)

c GC geographic co-ordenates; all samples are within the $30 \mathrm{~T}$ zone of the Universal Transverse Mercator co-ordinate system

${ }^{d}$ Total $\mathrm{Fe}$ expressed as $\mathrm{Fe}_{2}{ }_{3}$, with the only exception of samples 76547 and 78846 . NA: not analysed. bdl: below detection limit

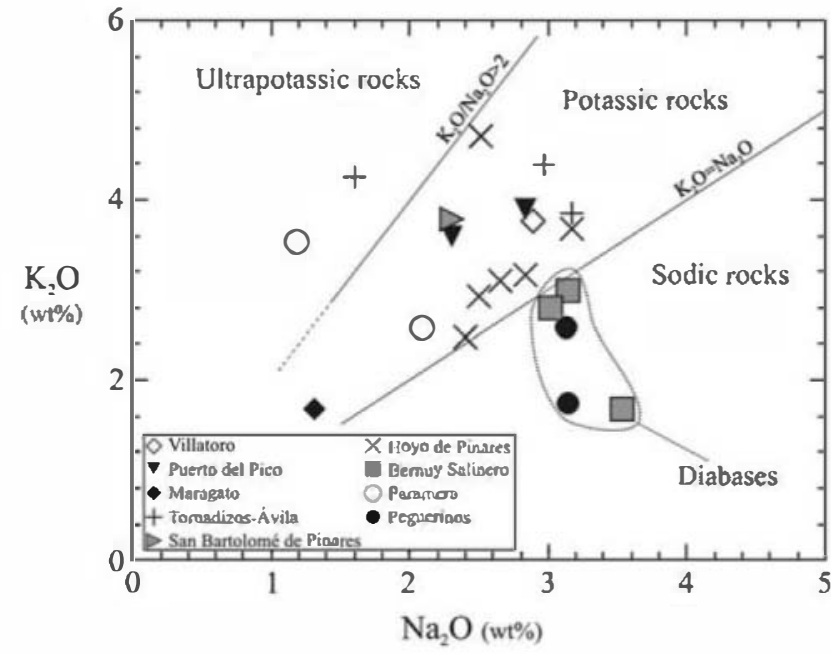

Fig. $4 \mathrm{~K}_{2} \bullet$ versus $\mathrm{Na}_{2} \bullet(\mathrm{wt} \%)$ contents of the SCS alkaline basic dykes. The line for $\mathrm{K}_{2}-\mathrm{Na}_{2}-2$, which separates potassic from ultrapotassic rocks has been constructed with the criteria of Foley et al. (1987)

composition is observed in the Permian alkaline basic dykes from the western Alps (Fig. 8).

$\mathrm{The} \mathrm{Sr}-\mathrm{Nd}-\mathrm{Pb}$ isøtopic composition of the SCS alkaline magmatism represents the irruption of a new mantlederived component in the Central-Iberian Zone. The PREMA-like alkaline dykes contrast with the previøus calc-alkaline Hercynian basic magmatic suites (Gb1, Gb2 and Gb3; Villaseca et a1. 2004) that are clearly lithospherederived $\left({ }^{87} \mathrm{Sr} /{ }^{86} \mathrm{Sr} \bullet\right.$ ranging from 0.7045 t॰ 0.7087 and $\varepsilon \mathrm{Nd}$ from -3.9 to +0.6; Fig. 7). This new component is not recorded previøusly in the whole Hercynian Iberian Massif, suggesting a significant geodynamic change during postHercynian times, this is discussed in more detail below.

\section{Petrogenesis}

Magma differentiation

One of the main features of the SCS Permian alkaline magmatism is its chemical and perological heterogeneity, giving rise to the lamprophyre-diabase division and variable phenocryst modal composition. These characteristics are alsø manifested in the absence of a unique variation rend for the group of dykes as a whøle for many majør and race elements (e.g. Ti, $\mathrm{K}, \mathrm{V}, \mathrm{Rb}, \mathrm{Zr}$ ), although there are both negative and positive correlations between these elements and $\mathrm{Mg} \#$ when considering the samples of each dyke separately (Fig. 5). This heterogeneity could be explained by the intrusion of several magma batches derived from slightly different mantle sources, or it might be caused by variable amounts of melting. We regard the $\mathrm{Sr}-\mathrm{Nd}$ is 


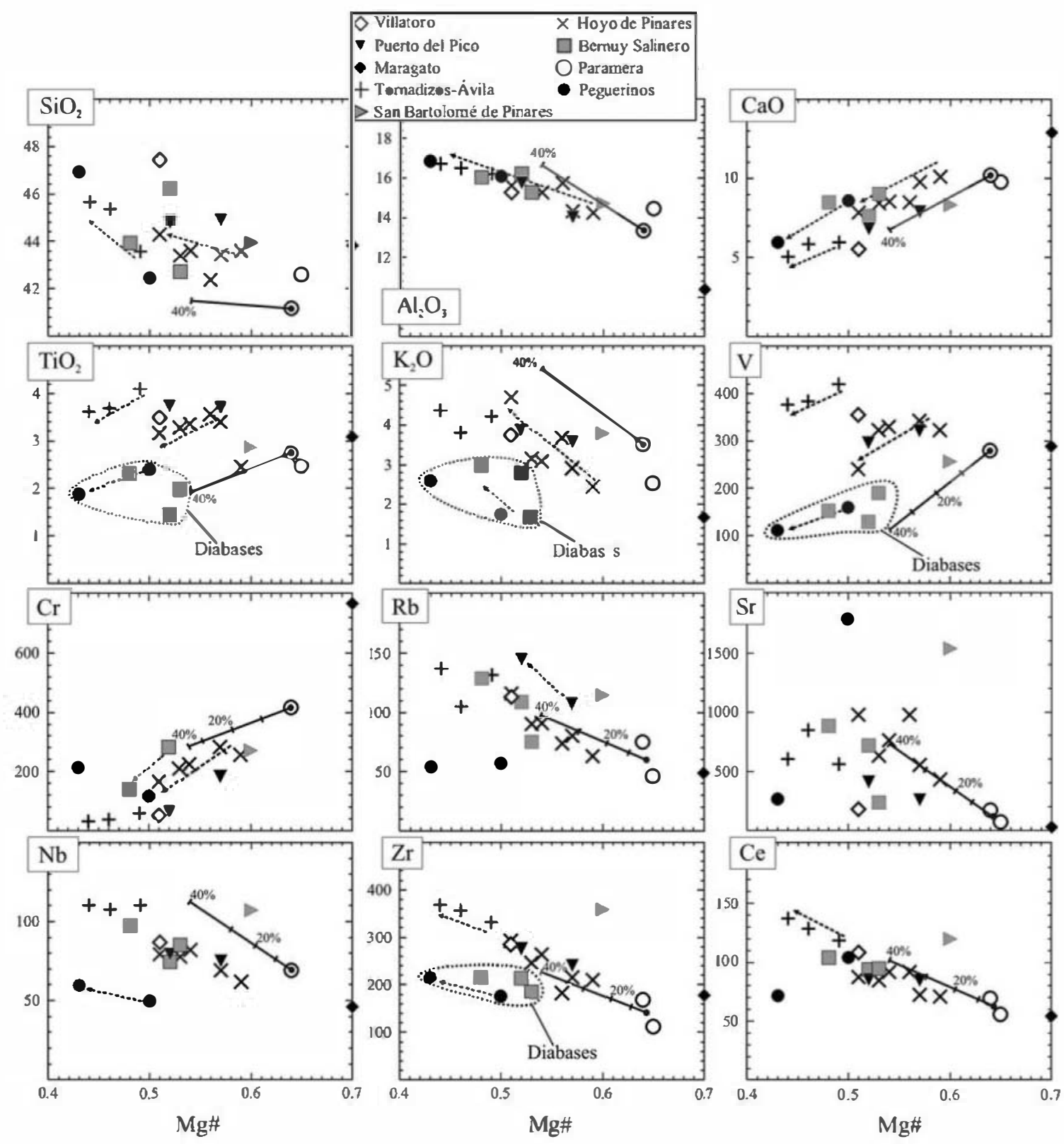

Fig. 5 Major and trace element composition of the SCS alkaline basic dykes. Concentrations expressed as weight $\%\left(\mathrm{Si}_{2}, \mathrm{Al}_{2} \boldsymbol{\bullet}_{3}, \mathrm{Ca}, \mathrm{Ti} \boldsymbol{\bullet}_{2}\right.$ and $\left.\mathrm{K}_{2}\right)$ and $\mathrm{ppm}(\mathrm{V}, \mathrm{Cr}, \mathrm{Rb}, \mathrm{Sr}, \mathrm{Nb}, \mathrm{Zr}$ and $\mathrm{Ce})$. The black arrows indicate the compositional variation rend observed within samples from a single dyke. The solid grey line displays the output data of a fractional crystallization model applied on major and trace elements and made on the basis of the general Rayleight equation. The model input ata consider fractionation of $20 \% \mathrm{cpx}, 7 \%$ ol and $13 \% \mathrm{amph}$, obtaine by averaging phenocrysts modal proportions. Clinopyroxene 103811-62, amphibole 80318-9 and olivine 104867-57 from Tables 1

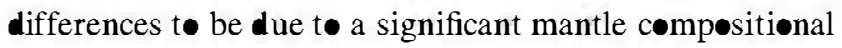
effect. This is discussed below.

Spanish Central System alkaline rocks do not show primary magma compositions according to the criteria $\bullet$ Frey et al. (1978): $\mathbf{M g \#}>\mathbf{0 . 6}-\mathbf{0 . 7} ; \mathrm{Cr}>\mathbf{5 0 0}-1, \mathbf{0 0 0} \mathrm{ppm}$ and $\mathrm{Ni}>\mathbf{2 0 0}-500 \mathrm{ppm}$ (Table 3). Moreover, the forsterite and 2 have been use in major element modeling. As initial magma composition we have considere the most $\mathrm{Mg}$-rich non cumulate samples from La Paramera dyke (76547 and 77753). Mineral/melt partition coef ficients for clinopyroxene, olivine and amphibole used for modeling race elements (except $\mathrm{Cr}, \mathrm{V}$ ) taken, respectively, from Foley et al. (1996), Zanetti et al. (2004) (except Nb after Taura et al. 1998) and LaTourrette et al. (1995). $\mathbf{D}_{C r}^{C p x / m e l t}, \mathbf{D}^{C p x / m e l t}$ and $\mathbf{G}^{1 / m e l t}$ after Ringwood (1970); $\mathbf{D}_{\mathbf{V}}^{\mathrm{Amp} / \mathrm{melt}}$ and $\mathbf{D}_{\mathbf{v}}^{\mathrm{i} / \mathrm{melt}^{2}}$ after Dostal et al. (1983) and $D_{\mathrm{Cr}}^{\mathrm{Amph} / \mathrm{melt}}$ after Matsui et al. (1977)

content $\bullet$ elivines frøm primary magmas are normally in the range 88-94, whilst $\bullet$ livines from SCS lamprophyres and diabases do not exceed $\mathrm{F}_{86}$, suggesting the invelvement $\bullet$ one or more differentiation processes. Of particular interest is the alkaline dyke from Maragate, which shows the richest composition in $\mathrm{Mg}, \mathrm{Cr}$ and $\mathrm{Ni}$ (Fig. 5). These 
Fig. 6 a Chondrite-normalised and $b, c$ and $d$ primitive mantlenormalised race element composition of the SCS alkaline basic dykes. Lamprophyres containing phlogopite phenocrysts and diabasic samples have been plotted separately for race element spidergrams, whereas they all have been plotted together for REE. The normalising values of chondrite and primitive mantle are after Sun and $\mathrm{McD}$ onough (1989) and McDonough and Sun (1995), respectively (a)

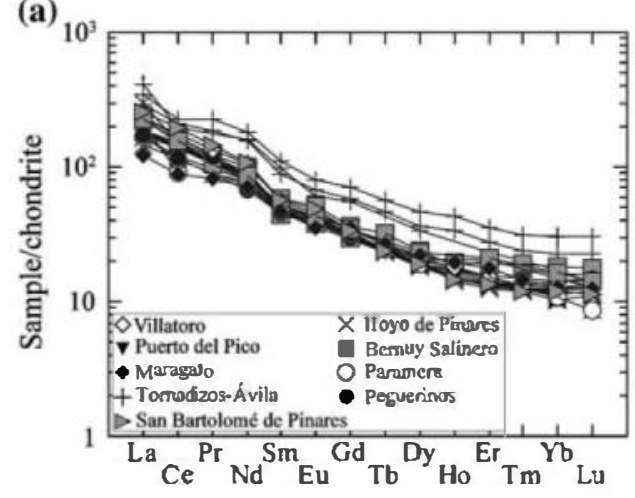

(b)
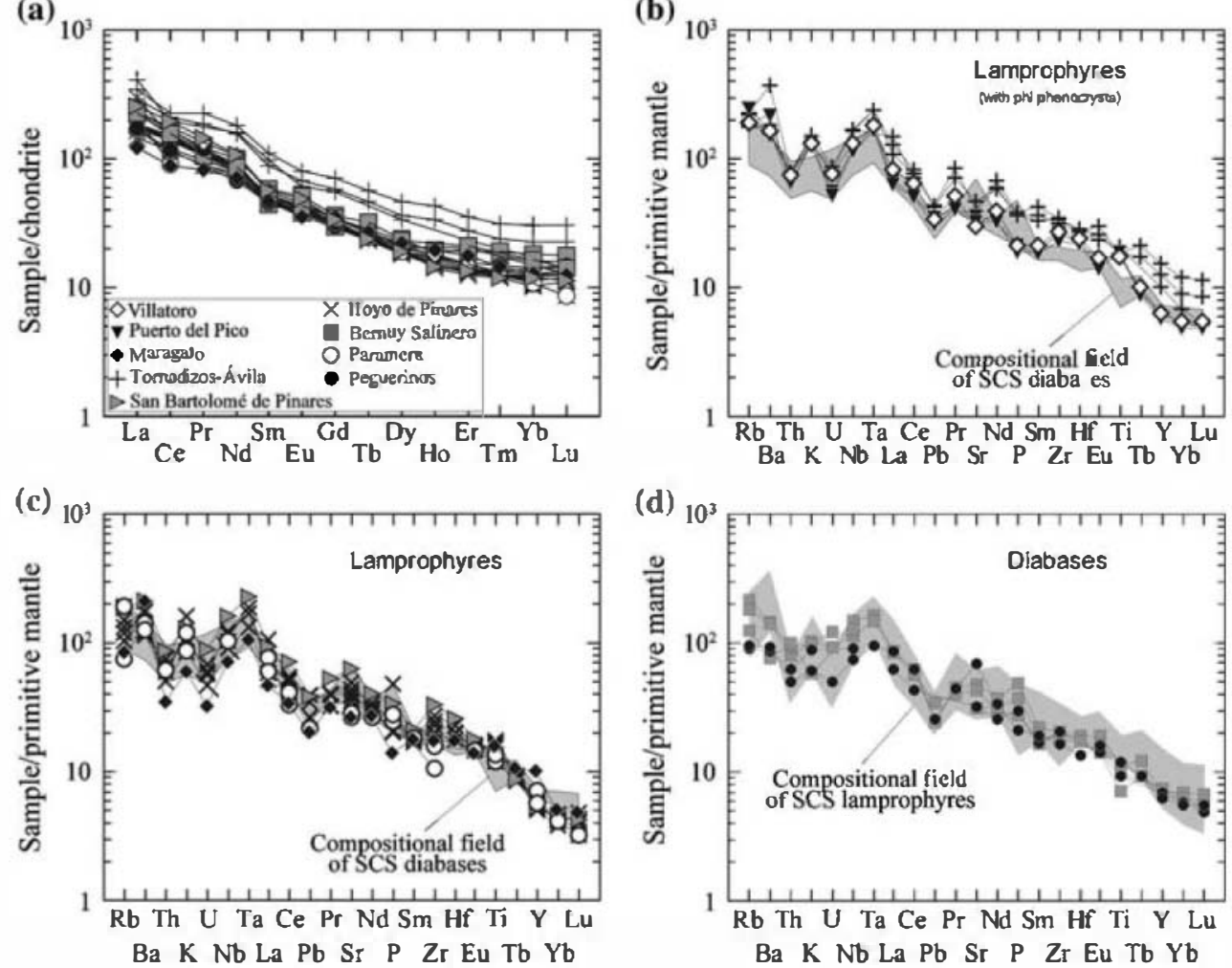

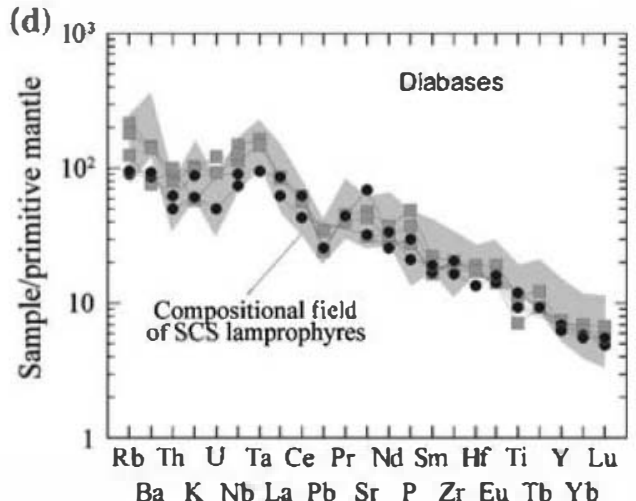

contents are probably influenced by the cumulative nature of this dyke, as deduced from its high proportion (>40\%) -f mafic phenocrysts (mainly clinopyroxene and pseudomorphosed elivine).

The positive correlation of $\mathrm{Ca}, \mathrm{Ni}, \mathrm{Cr}$ and $\mathrm{V}$ versus $\mathrm{Mg} \#$ value points to $\bullet+\mathrm{Cr}$-sp $+\mathrm{cpx}$ crystal fractionation. Additionally, the trends of Ti depletion observed in Fig. 5 are likely to be due to kaersutite fractionation. These premises are consistent with the petrographic observations. We have applied a crystal fractionation model based on major and trace elements for the lamprophyric melts; the results are plotted in Fig. 5. A $40 \%$ fractionation of $\mathrm{cpx}+\mathrm{amph}+\bullet 1$ is enough to account for the compositional trends observed in the SCS lamprophyric magmas (more details in caption to Fig. 5). This model should be considered as a general indication of the fractionation process followed by the different alkaline dyke swarms (e.g. for diabasic magmas a different crystal fractionation process invelving plagiøclase shøuld be considered).

\section{Røle of crustal assimilation}

The entrapment of granulite and cumulate ultramafic xenoliths whose estimated pressure of equilibration ranges from 7 t $12 \mathrm{kbar}$ (Villaseca et al. 1999; Orejana et al. 2006) seems to indicate that the SCS lamprophyric and diabasic melts might have stagnated at lower crustal levels. This is reinforced by the fact that some of those ultramafic cumulate xenoliths are genetically related with the Permian alkaline magmatism (Orejana et al. 2006), and alse because søme lamprophyres carry a complex high-pressure phen॰cryst population (Orejana et al. 2007). Thus, the question of a possible lower crustal contamination process arises. Ratios of trace elements with contrasting concentrations in mantle and crustal rocks may help to evaluate this possible influence. $\mathrm{Ce} / \mathrm{Pb}$ and $\mathrm{Ba} / \mathrm{Nb}$ ratios in the continental crust are around 3.9 and 57, respectively (Rudnick and Ga 2003) due the high $\mathrm{Pb}$ and $\mathrm{Ba}$ concentrations in the crust. These values are close to those of the SCS granulite xenoliths from the lower crust $(\mathrm{Ce} / \mathrm{Pb} \sim 5$ and $\mathrm{Ba} / \mathrm{Nb} \sim 66$; Villaseca et al. 1999). The same raties in the SCS alkaline lamprophyres and diabases are significantly different (Ce/ $\mathrm{Pb}=14-28$ and $\mathrm{Ba} / \mathrm{Nb}=9-15)$, approaching the trace element composition of typical mantle-derived rocks (OB: $\mathrm{Ce} / \mathrm{Pb} \sim 25$ and $\mathrm{Ba} / \mathrm{Nb} \sim 7.3$; Sun and McDonough 1989) (Fig. 9a). Three SCS lamprophyres shøw Ba/Nb frøm 15 t॰ 29, although these high values are prøbably derived frøm the high proportions of phløgøpite (Ba-rich) and clinøpyroxene (Nb-poor) phenocrysts.

We have tested an AFC model using $\mathrm{Ce} / \mathrm{Pb}$ and $\mathrm{Ba} / \mathrm{Nb}$ ratios tø quantify the degree of assimilation of lower crustal materials on the composition of the SCS alkaline dykes (see input data in Fig. 9 caption). The results shown in Fig. 9a are based on three different assimilation/fractionation $(r)$ values. Leaving aside the three samples with high $\mathrm{Ba} / \mathrm{Nb}$ discussed above, the small compositional differences 
Table $4 \mathrm{Sr}-\mathrm{Nd}-\mathrm{Pb}$ Isotopic composition of SCS alkaline lamprophyres and diabases

\begin{tabular}{|c|c|c|c|c|c|c|c|c|c|}
\hline \multirow[b]{2}{*}{ Dyke } & \multicolumn{6}{|l|}{ Lamprophyres } & \multicolumn{3}{|l|}{ Diabases } \\
\hline & Paramera & $\begin{array}{l}\text { Tomadizos- } \\
\text { Ávila }\end{array}$ & Hoyo de Pinares & Maragato & Puerto del Pico & San Bartolomé de Pinares & Bernuy Salinero & Peguerinos & Peguerinos \\
\hline Sample & $77753^{\mathrm{a}}$ & $103473^{\mathrm{a}}$ & $103674^{\mathrm{a}}$ & 103811 & 103818 & $104541^{b}$ & $81839^{b}$ & $81938^{\mathrm{a}}$ & $101892^{b}$ \\
\hline $\mathbf{R b}(\mathrm{ppm})$ & 74 & 137 & $\$ 1.4$ & 489 & 107 & 115 & 129 & 54 & 56.5 \\
\hline $\mathrm{Sr}(\mathrm{ppm})$ & 429 & 803 & 880 & 514 & 631 & 1266 & 942 & 633 & 1387 \\
\hline${ }^{87} \mathbf{R b} /{ }^{86} \mathrm{Sr}$ & 0.50 & 0.49 & 0.30 & 0.28 & 0.49 & 0.26 & 0.40 & 0.25 & 0.12 \\
\hline${ }^{87} \mathrm{Sr} /{ }^{86} \mathrm{Sr} \pm(2 \sigma)$ & $0.704850 \pm 03$ & $0.706246 \pm 06$ & $0.705803 \pm 05$ & $0.706147 \pm 32$ & $0.707004 \pm 23$ & $0.705798 \pm 07$ & $0.705276 \pm 12$ & $0.704455 \pm 06$ & $0.703741 \pm 08$ \\
\hline${ }^{87} \mathrm{Sr}^{86} \mathrm{Sr}_{265 \mathrm{Ma}}$ & 0.70297 & 0.70438 & 0.70467 & 0.70511 & 0.70515 & 0.70481 & 0.70378 & 0.70352 & 0.70330 \\
\hline $\operatorname{Sm}(\mathrm{ppm})$ & 7.12 & 16.9 & 7.45 & 7.07 & 7.37 & 8.69 & 891 & 691 & 7.65 \\
\hline $\mathrm{Nd}(\mathrm{ppm})$ & 35.2 & 84.4 & 429 & 33.2 & 39.6 & 509 & 46.5 & 31.68 & 42.2 \\
\hline${ }^{147} \mathrm{Sm} /{ }^{144} \mathrm{Nd}$ & 0.122 & 0.121 & 0.105 & 0.129 & 0.113 & 0.103 & 0.116 & 0.132 & 0.110 \\
\hline${ }^{143} \mathrm{Nd} /{ }^{144} \mathrm{Nd} \pm(2 \sigma)$ & $0.512841 \pm 08$ & $0.512465 \pm 03$ & $0.512551 \pm 04$ & $0.512523 \pm 05$ & $0.512444 \pm 06$ & $0.512500 \pm 06$ & $0.512860 \pm 10$ & $0.512728 \pm 03$ & $0.512832 \pm 05$ \\
\hline $\mathrm{e}(\mathbf{N d})_{265 \mathrm{Ma}}$ & 6.5 & -0.8 & 1.4 & 0.1 & -0.9 & 0.5 & 7.1 & 4.0 & 6.7 \\
\hline $\mathrm{U}(\mathrm{ppm})$ & 132 & 1.75 & 1.19 & & 1.03 & 1.82 & 1.87 & & 1.02 \\
\hline Th (ppm) & 5.00 & 6.21 & 526 & & 5.17 & 6.94 & 6.42 & & 4.01 \\
\hline $\mathbf{P b}(\mathrm{ppm})$ & 328 & 6.56 & 5.47 & & 4.67 & 6.09 & 3.65 & & 4.56 \\
\hline${ }^{238} \mathrm{U} /{ }^{2 \cdot 4} \mathrm{~Pb}$ & 30.0 & 19.4 & 17.0 & & 17.2 & 22.8 & 37.4 & & 17.0 \\
\hline${ }^{232} \mathrm{Th} /{ }^{2}{ }^{-4} \mathrm{~Pb}$ & 125.0 & 69.0 & 75.1 & & 86.2 & 86.8 & 128.4 & & 66.8 \\
\hline${ }^{206} \mathrm{~Pb} /{ }^{204} \mathbf{P b} \pm(2 \sigma)$ & $19.548 \pm 0.006$ & $19.281 \pm 0.004$ & $19.047 \pm 0.020$ & & $19.129 \pm 0.010$ & $19.411 \pm 0.010$ & $19.808 \pm 0.040$ & & $19225 \pm 0.014$ \\
\hline${ }^{207} \mathbf{P b} /{ }^{204} \mathbf{P b} \pm(2 \sigma)$ & $15.675 \pm 0.006$ & $15.617 \pm 0.004$ & $15.640 \pm 0.020$ & & $15.680 \pm 0.010$ & $15.649 \pm 0.010$ & $15.629 \pm 0.040$ & & $15.624 \pm 0.012$ \\
\hline${ }^{2{ }^{\circ}} \mathbf{P b} /{ }^{204} \mathbf{P b} \pm(2 \sigma)$ & $39.658 \pm 0.006$ & $39.268 \pm 0.004$ & $39211 \pm 0.020$ & & $39.582 \pm 0.010$ & $39.553 \pm 0.010$ & $39.632 \pm 0.040$ & & $39.180 \pm 0.014$ \\
\hline${ }^{206} \mathrm{~Pb} /{ }^{204} \mathrm{~Pb}_{(265 \mathrm{Ma})}$ & 18.163 & 18.465 & 18.334 & & 18.409 & 18.456 & 18239 & & 18512 \\
\hline${ }^{207} \mathrm{~Pb} /{ }^{204} \mathrm{~Pb}_{(265 \mathrm{Ma})}$ & 15.604 & 15.575 & 15.603 & & 15.643 & 15.600 & 15548 & & 15587 \\
\hline${ }^{208} \mathrm{~Pb} /{ }^{2}{ }^{4} \mathrm{~Pb}_{(265 \mathrm{Ma})}$ & 38.008 & 38.357 & 38.219 & & 38.445 & 38.408 & 37937 & & 38298 \\
\hline
\end{tabular}

$\mathbf{R b}, \mathrm{Sr}, \mathrm{Sm}, \mathrm{Nd}, \mathrm{U}, \mathrm{Th}$ and $\mathbf{P b}$ concentrations deternnined by ICP-MS

${ }^{a} \mathrm{Sr}-\mathrm{Nd}$ isotopic data of these samples taken from Villaseca et al. (2004)

b $\mathrm{Sr}-\mathrm{Nd}$ isotopic data of these samples taken from Orejana et al. (2006) 


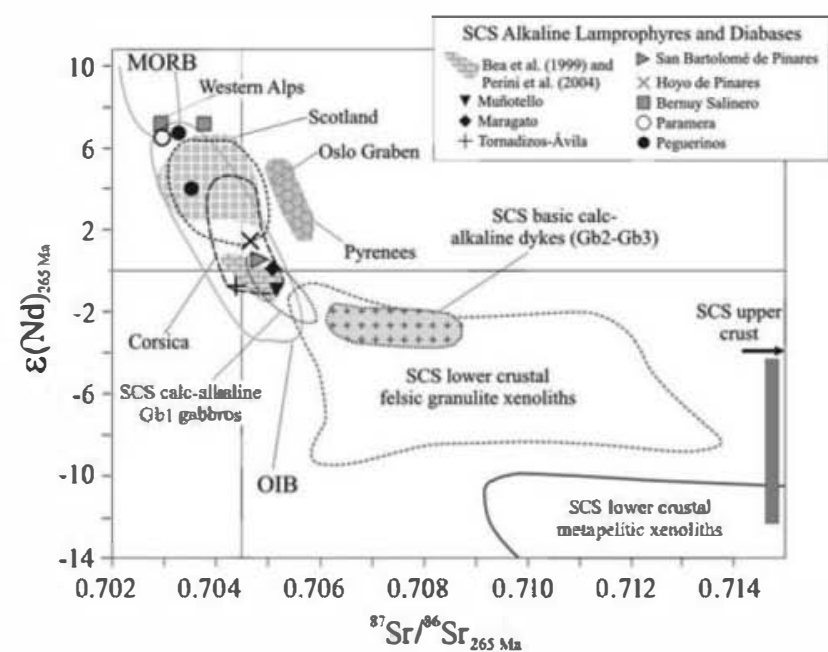

Fig. $7 \mathrm{Sr}-\mathrm{Nd}$ isotopic composition of the SCS alkaline basic dykes compared with that of other alkaline or moderately alkaline Permian basic rocks from westem Europe, including previous analyses of Bea et al. (1999) and Perini et al. (2004) for the SCS alkaline lamprophyres. Maragato and Puerto del Pico samples represent new data, whilst the rest of plotted samples are taken from Villaseca et al. (2004) and Orejana et al. (2006). Compositional field of Pyrenees, Oslo Graben, Scotland, Corsica and Western Alps are taken from Lago et al. (2004), Neumann et al. (2004), Upton et al. (2004), Bonin (2004) and Monjoie (2004), respectively. It has been also plotted for comparison the composition of the $\mathrm{Gbl}$ and $\mathrm{Gb} 2-\mathrm{Gb} 3$ calc-alkaline post-collisional dykes from the SCS, after Villaseca et al. (2004). The isotopic signatures of the SCS lower crustal felsic granulite xenoliths and metapelitic xenoliths are taken from Villaseca et al. (1999). SCS upper crustal materials (grey vertical bar) plot mostly out of the diagram, towards much higher ${ }^{87} \mathrm{Sr} /{ }^{86} \mathrm{Sr}$ values (Villaseca et al. 1998b). OIB and MORB fields after Wilson (1989)

displayed by the SCS alkaline dykes would require n॰ more than $7 \%$ assimilation of lower crustal rocks. Moreover, there is not a positive correlation of silica content with $\mathrm{Sr}$ is tope radiegenic ratios or $\mathrm{Rb} / \mathrm{Sr}$ values in these alkaline rocks (Fig. 9b,c), as would be expected if a silica-rich crustal component were invelved in their genesis. Additiønally, the negative $\mathrm{Pb}$ an॰malies and $\mathrm{Nb}$-Ta peaks shøwn by the SCS alkaline dykes when normalized to primitive mantle contents (Fig. 6), support the contention that contamination by lower crustal rocks did not exert a significant influence on their composition.

Søurce enrichment and mantle heterøeneity

The primitive mantle-normalise $\mathrm{Sm} / \mathrm{Yb}$ ratios in the SCS alkaline basic røcks range frøm 2.4 t॰ 5.3, and these values are consistent with melting in the presence of residual garnet (e.g. McKenzie and O'Niøns 1991). Furthermøre, their high incompatible trace element contents probably indicate the involvement of an enrichment process in the mantle source.

$\mathrm{Th} / \mathrm{Yb}$ and $\mathrm{Ta} / \mathrm{Yb}$ ratios in basic rocks are a useful petrogenetic indicator. In Fig. 10a we have represented the
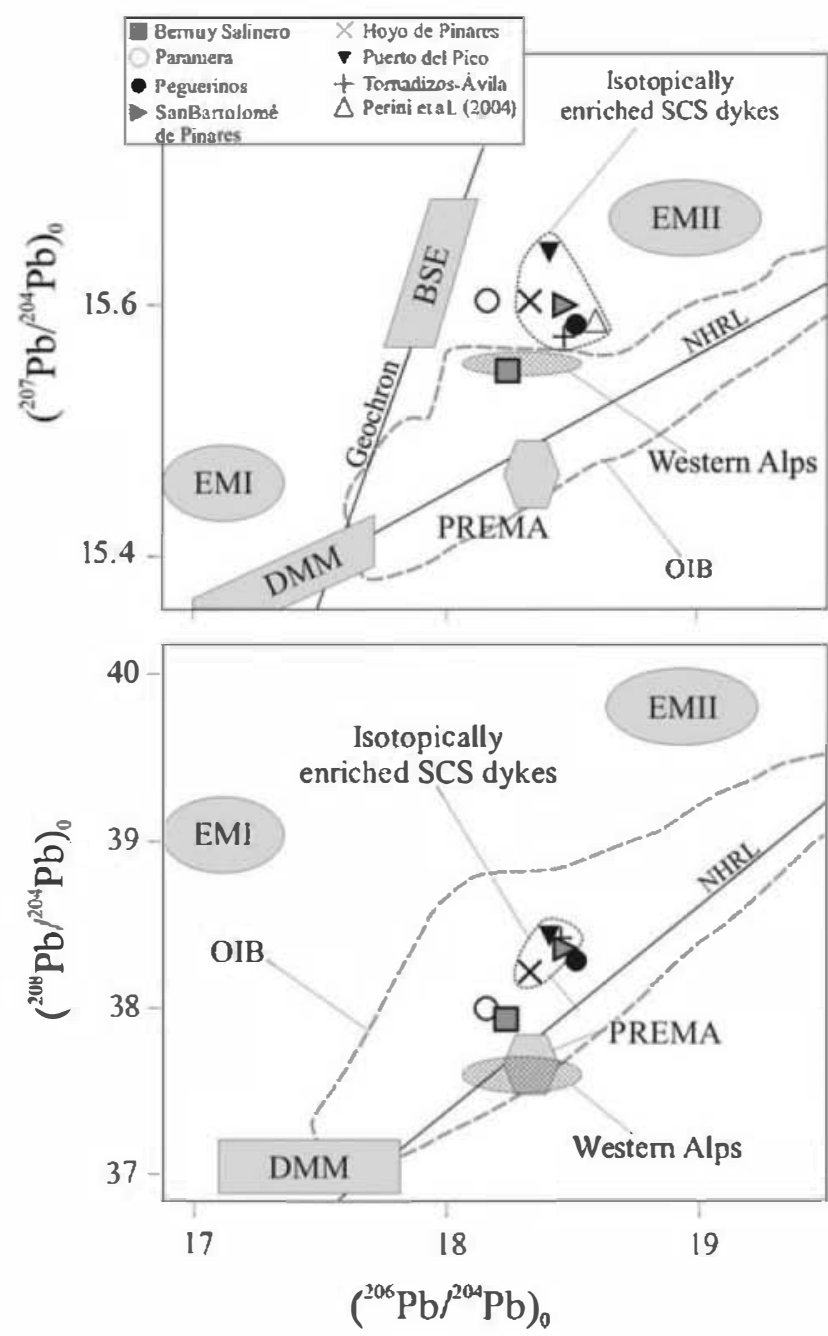

Fig. $8 \mathrm{~Pb}$ isotope ratios of the SCS alkaline basic dykes. The single data of Perini et al. (2004) corresponds with a single SCS alkaline lamprophyre. It has also been plotted for comparison the composiional field of the Permian moderately alkaline dykes from westem Alps (Mon joie 2004). Compositional fields of $1 \mathrm{IB}, \mathrm{DMM}, \mathrm{BSE}, \mathrm{EMI}$, EMII, PREMA and HIMU are taken from Zindler and Hart (1986). NHRL: Northern Hemisphere Reference Line

compositional fields of mantle-derived rocks from depleted and enriched sources (following the mantle array) and those of island arc basalts (IAB) and active continental margins (taken after Wilsøn 1989). The involvement of crustal rocks or subduction components in IAB and continental margins is reflected in their Th enrichment and Ta depletion with respect to REE. The SCS alkaline basic dykes plot within the mantle array and completely overlap the enriched field of mantle rocks, with a composition similar to OB (Fig. 10a), thus supporting a minor contribution of crustal assimilation and suggesting that primary magmas of these rocks were generated by partial melting of a metas matised mantle.

For SCS alkaline lamprophyres there are positive correlations between $\mathrm{Rb} / \mathrm{La}$ and $\mathrm{K} / \mathrm{La}$ ratios, and alsø between 
Fig. 9 Whole-rock chemical composition of SCS alkaline basic dykes for a $\mathrm{Ce} / \mathrm{Pb}$ versus $\mathrm{Ba} / \mathrm{Nb}, \mathbf{b} \mathrm{Si}_{2}$ versus $\mathrm{Rb} / \mathrm{Sr}$ and $\mathbf{c} \mathrm{Si}_{2}$ versus $\left({ }^{87} \mathrm{Sr} /{ }^{86} \mathrm{Sr}\right.$.). Plot (a) also shows an $\mathrm{AFC}$ model made for three contrasing assimilation/fractionation ratios $(0.2,0.5$ and 0.8$)$. Initial model melt composition: sample 77753 (La Paramera dyke). Contaminant composition: averaged values of SCS lower crustal granulite xenoliths (Villaseca et al. 1999). The bulk $\mathrm{D}_{\mathrm{Nb}}(0.06), \mathrm{D}_{\mathbf{B a}}$ $(0.05), \mathrm{D}_{\mathrm{Ce}}(0.07)$ and $\mathbf{D}_{\mathbf{P b}}(0.03)$ have been calculated using the mineral/melt partition coefficients and the proportions of ractionating phases described in Fig. 5 caption, with the exception of $D_{P b}$, for which $\mathrm{ol} / \mathrm{melt}$ and amph/melt partition coefficients have been taken from McKenzie and 'Nions (1991). MORB and OIB average composition in diagram (a) are taken from Sun and McDonough (1989)

$\mathrm{Ba} / \mathrm{Nb}$ and $\mathrm{Ba} / \mathrm{Ce}$ ratios (Fig. $10 \mathrm{~b}, \mathrm{c}$ ). These features might account før the presence of phløg pite in the søurce during partial melting as this mineral may preferentially incorporate LLE when compared to REE and HFSE. This is alsø supported by the potassic character of lamprophyres; potassic and ultrapotassic rocks are associated with the presence $\bullet$ phløg pite in the mantle (e.g. F•ley 1992). The high $\mathrm{Nb}-\mathrm{Ta}$ concentrations observed in the SCS alkaline dykes (Table 3) suggest that pargasitic amphibøle has als• participated in their genesis controlling the behavior of $\mathrm{Nb}-\mathrm{Ta}$ during mantle melting (e.g. Ionov et a1. 1997). Morever, the SCS diabases have higher $\mathrm{Nb} / \mathrm{Ta}$ ratios (13.6-16.1) when compared to the lamprophyres (11.213.1). Green (1995) found that pargasite is the only mineral involved in the genesis of basaltic magmas that shows $\mathrm{D}_{\mathrm{Nb}}$ $\mathrm{Ta}>1$, and thus the melt $\mathrm{Nb} / \mathrm{Ta}$ ratio is controlled by

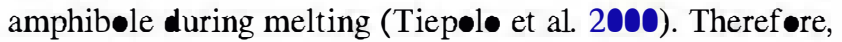
although both potassic phases might have coexisted, amphibøle was probably predominant in the mantle sources -f SCS diabases, whilst the influence of phlogøpite is evident mainly in the case of lamprophyres. The moderate $\mathrm{P}_{2} \mathbf{\Theta}_{5}$ content $\bullet$ the SCS alkaline dykes (0.3-1 wt\%; Table 3) indicate that a P-rich phase, such as apatite, might have been a stable metasmatic mineral in the mantle source. Slight negative $\mathrm{P}$ anømalies can be observed in these dykes (Fig. 6) indicating the presence of a residual $P$-rich mineral in the mantle. Samples showing positive $P$ anomalies are those characterized by high propørtions of accumulated apatite phenocrysts (e.g. sample 81839).

A diabase-lamprophyre association within the PermoCarbøniferøus magmatism in western Eurøpe has alsø been reported in southern Scandinavia by Obst et al (2004). Nevertheless, these diabases are tholeiitic in composition and they are derived from a depleted mantle source subjected to metasomatic event that is genetically unrelated to the coeval alkaline lamprophyres. On the contrary, the SCS diabase-lamprophyre asseciation consists of similar alkaline magma batches (e.g. Fig. 6), which alsø •verlap in their $\mathrm{Sr}-\mathrm{Nd}-\mathrm{Pb}$ isøtopic compositional fields, suggesting that they are derived from similar mantle søurces with only slight differences in their modal accessory mineralogy. (a)

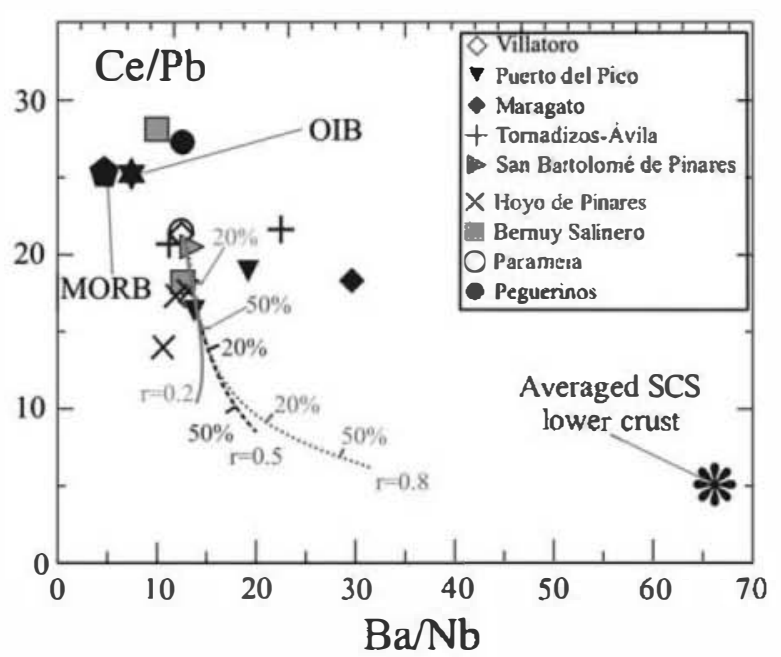

(b)

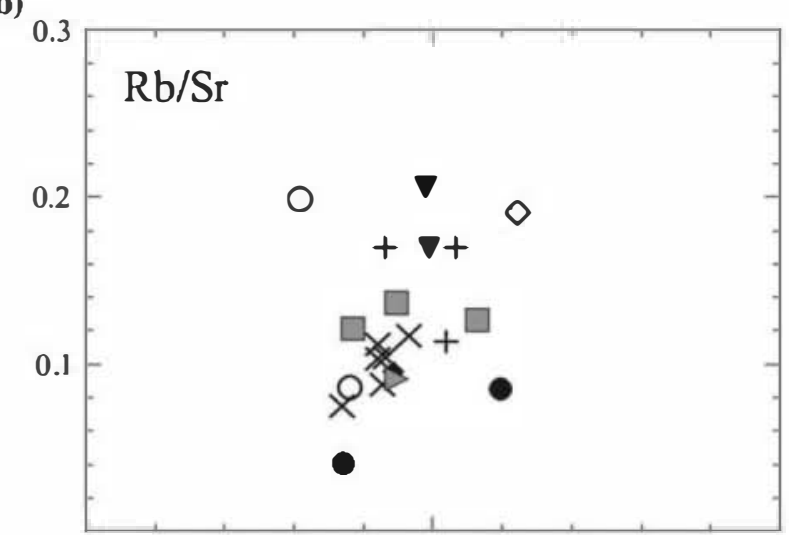

(c)

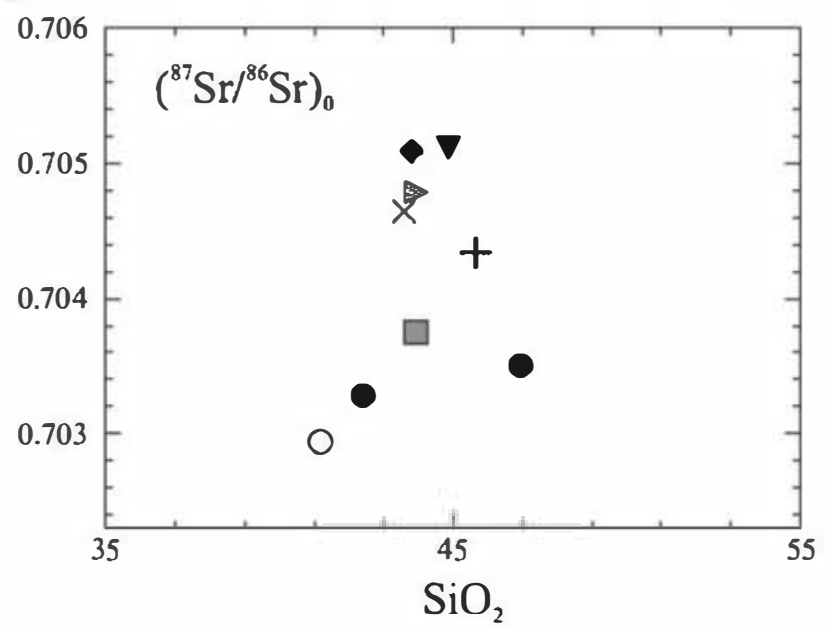

The is $\bullet$ pic composition $\bullet$ the SCS alkaline magmas implies the inv lvement of at least tw• different mantle sources: one isøtopically depleted (PREMA-like) and the -ther is topically enriched. The depleted $\mathrm{Sr}-\mathrm{Nd}$ is tope signatures of diabases and some lamprophyres indicate participation of a sublithøspheric source (prøbably asthenosphere-related). However, the lamprophyres with more radiogenic $\mathrm{Sr}-\mathrm{Nd}$ isøtopic compositions clearly 

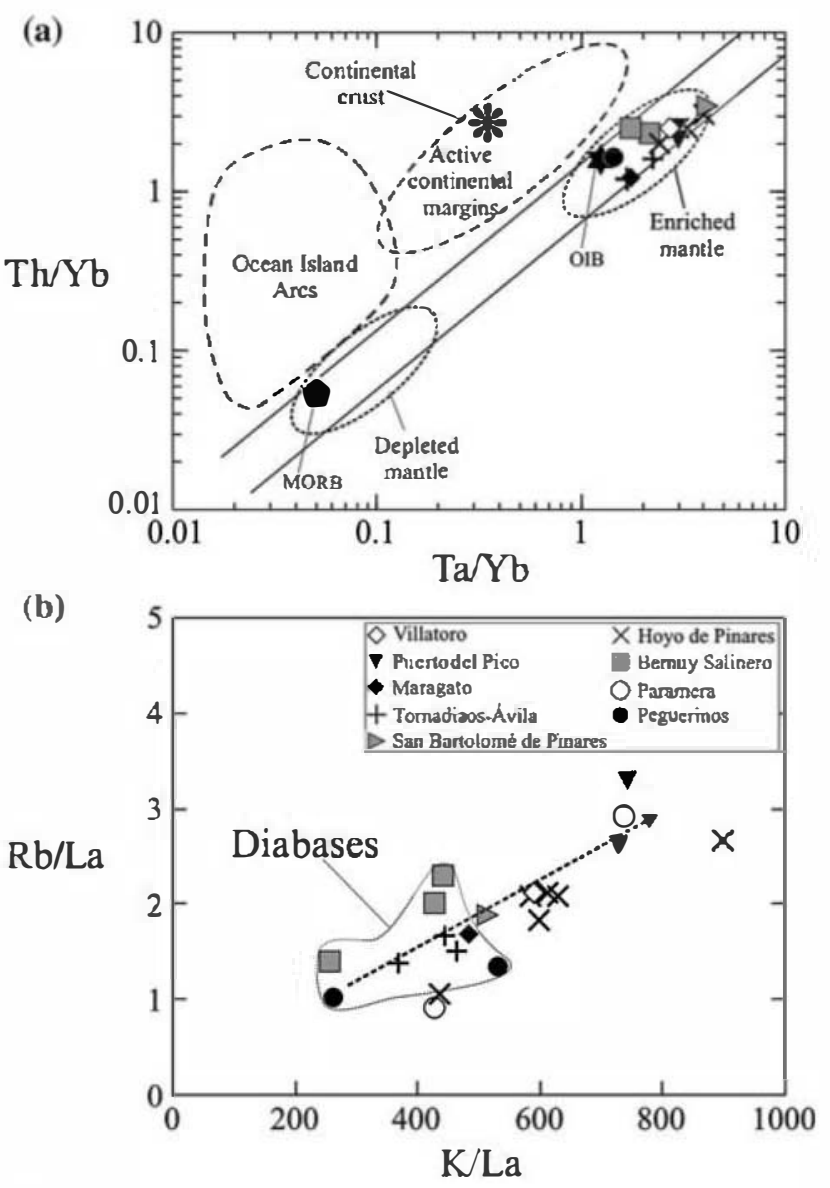

(c)

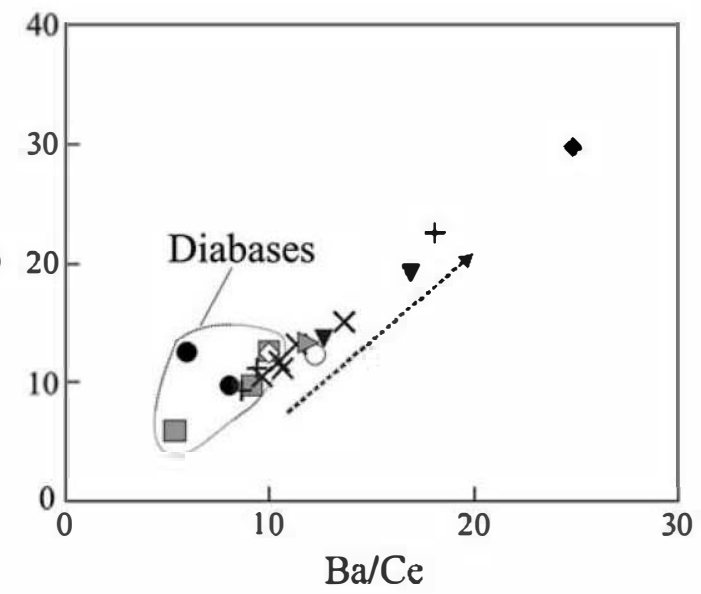

Fig. 10 Whole-rock chemical composition of SCS alkaline basic dykes for a $\mathrm{Th} / \mathrm{Yb}$ versus $\mathrm{Ta} / \mathrm{Yb}$, b Rb/La versus $\mathrm{K} / \mathrm{La}$ and $\mathbf{c} \mathrm{Ba} / \mathrm{Nb}$ versus $\mathrm{Ba} / \mathrm{Ce}$. Arrows represent the general rend described by the SCS alkaline dykes. MORB and OIB average composition in diagram (a) are taken from Sun and McDonough (1989), and Continental crust average composition taken from Rudnick and Gao (2003). The fields of Oceanic Island Arcs and Active Continental Margins after Wilson (1989)

indicate the invelvement of a lithospheric mantle. Metasømatism of both asthenospheric and lithospheric mantle søurces is likely to have acted in a similar way, producing the same enrichment patterns; the highly incompatible race element ratios in both lamprophyres and diabases are n॰t significantly different (e.g. Fig. 10a).

Mantle metas@matism has been attributed t• either (1) fluids or melts generated by subduction processes (e.g. Peacock 1990), or (2) volatile- and K-rich, low-viscosity melts that leak from the asthenosphere and accumulate in the overlying lithosphere (e.g. McKenzie 1989). The composition of these agents is believed to change continuously as they percolate thorøugh the mantle from their source regions (Navon and Stølper 1987). Normalised multi-element plots (Fig. 6) for the SCS alkaline basic

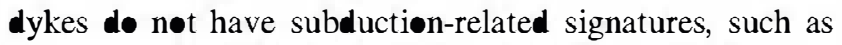
large negative $\mathrm{Nb}, \mathrm{Ta}$ and $\mathrm{Ti}$ anomalies, and thus we attribute the source enrichment to metas matising melts derived from the convecting mantle. McKenzie (1989) suggested that these melts would freeze in the lithosphere and might concentrate in thin zones over long periods of time, resulting in substantial volumes accumulated as veins, sills or dykes in a mechanical boundary layer. Melting of this metasøatised mantle might lead to the generation of pøtassic-ultrapøtassic røcks (e.g. Chalapathi Ra॰ et a1. 2004). The potassic nature of the SCS alkaline lamprophyres is in accordance with this latter model.

The involvement of a continental component in the SCS lamprophyre mantle søurces is difficult to assess. The Sr$\mathrm{Pb}$ is topic signatures of the enriched lamprophyres are indicative of the introduction of a ${ }^{87} \mathrm{Sr}-{ }^{207} \mathrm{~Pb}-{ }^{208} \mathrm{~Pb}$-rich component int the mantle. These characteristics cannot be explained by the generation of phlogøpite in mantle sources during the metasmatic event. This mineral usually displays high $\mathrm{Rb} / \mathrm{Sr}$ and low $\mathrm{U} / \mathrm{Pb}$ ratios, thus an enrichment in radiegenic $\mathrm{Pb}$ would not be expected. Furthermore, the high Rb-REE concentrations in the is topically depleted dykes argue against extended evolution of the mantle sources after being metasomatised. We consider that the ${ }^{207} \mathrm{~Pb}-{ }^{208} \mathrm{~Pb}$-rich composition of these rocks could be derived frøm a component similar to the reservøir EMI, which could be related the incorporation of continental crust inte the mantle (Zindler and Hart 1986). The subcontinental lithospheric mantle source of these lamprophyres has been slightly modified by subducted crustal components, nøw only detectable because of their is $\bullet$ pic signatures. But the origin and age of this metasøatic event is difficult to establish with the current data.

The geodynamic context of the SCS alkaline magmatism within the Permian magmatic province of western Europe

The intrusion of the SCS alkaline magmas is considered to be part of the widespread magmatism developed in western Europe at the end of the Hercynian orogeny, with extensive 
alkaline magmatic manifestations from the northern foreland to the internal zones (Wilson et al. 2004 and references therein). In Fig. 11 we have highlighted the location of the most important Permian basic magmatic regions in western Europe, together with the main structural lineations that were active at that time (see references in Fig. 11 caption). According to different studies, this Permian magmatism coincided with a period of incipient regional rifting (Bønin 1988; Ziegler 1993; Heeremans et al. 2004). Nevertheless, a palaeomagnetic study on Permian volcanic rocks from the western Alps has shown that a single geodynamic setting might not be applicable to the whole area (Muttoni et al. 2003). These authors propose that part of the S-Europe region would have been assembled with Africa (Gondwana) during Early Permian times. This is in agreement with the model of Irving (1977), which suggests that a significant change might have -ccurred in the palaeogeographic configuration of the Pangea supercontinent from early to late Permian, placing Gondwana farther to the East by approximately $3,000 \mathrm{~km}$ with respect to Laurasia at the beginning of this periød.
This transition from Pangea ' $\mathrm{B}$ ' to Pangea ' $\mathrm{A}$ ' has been asseciated with an intraplate dextral megashear system and with the reactivation of Hercynian shear zones (Muttoni et al. 2003). The Hercynian front could be related to one of these megashear bands.

Figure 12 shows the time intervals of Permian basic magmatism as a function of magmatic affinity (calc-alkaline, alkaline and thøleiitic) within western Europe. Calc-alkaline rocks are clearly confined to lower Permian or ølder ages within SW Europe and do not coexist with alkaline intrusions in the internal zone of the orogen, with the exception of Corsica-Sardinia (Cocherie et al. 2005) (Fig. 12). Additionally, Carboniferous alkaline rocks are confined t• NW Eurøpe. In Scotland this magmatism starts in the Dinantian (from $342 \pm 1 \mathrm{Ma}$; Monaghan and Pringle 2004) and persists during Permian times (Upton et al. 2004; Kirstein et al. 2006). Something similar is observed in the Osle Graben, where alkaline basalts were intruded between 305 and $299 \mathrm{Ma}$ and larvikitic and basanite lavas follow in several stages until 243 Ma (Neumann et al. 2004). Highly alkaline basalts and basanites are characteristic of the lower Permian

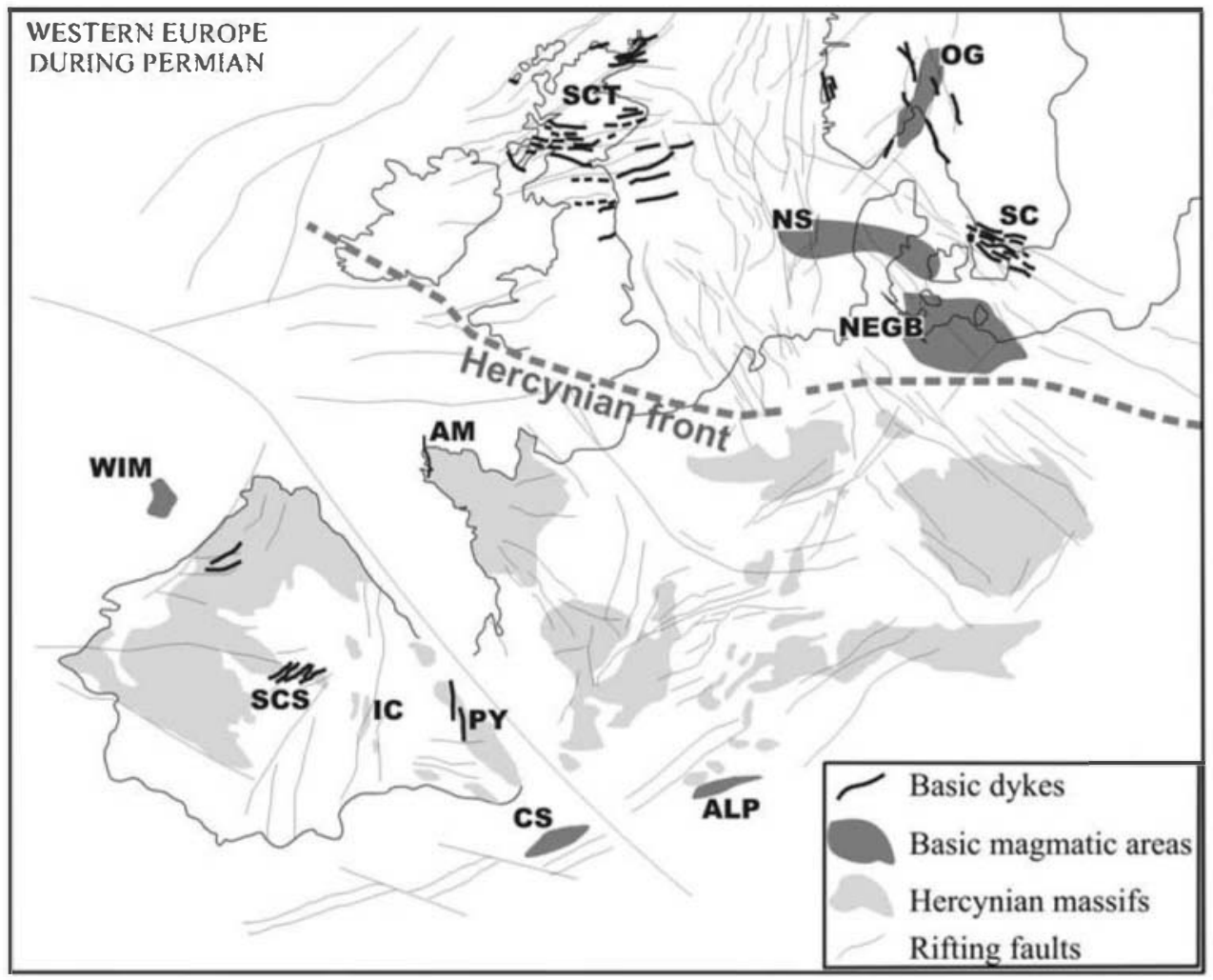

Fig. 11 Sketchy map made after Franke (1989) showing the location of the main magmatic regions within western Europe during Permian. WIM West Iberian Margin, after Gardien and Paquette (2004); P Portugal, after Portugal-Ferreira and Macedo (1977); PY Pyrenees, after Debon and Zimmermann (1993) and Lago et al. (2004); IC Iberian Chain, after Lago et al. (2005); AM Ammorican Massif, after Bellon et al. (1988); CS Corsica-Sardinia, after Bonin (1988); ALP western and southern Alps, after Cortesogno et al. (1998) and
Rottura et al. (1998); SCT Scotland, after Upton et al. (2004); NS North Sea, after Heeremans et al. (2004) and Stemmerik et al. (2000); $N E G B$ North East German Basin, after Neumann et al. (2004), $G$ -slo Graben, after Neumann et al. (2004) and SC Scania, after Neumann et al. (2004). Structural lineations after Bonin (1988), Ziegler (1993), Heeremans et al. (2004) and Ziegler et al. (2004). Hercynian front after Kirstein et al. (2006) 


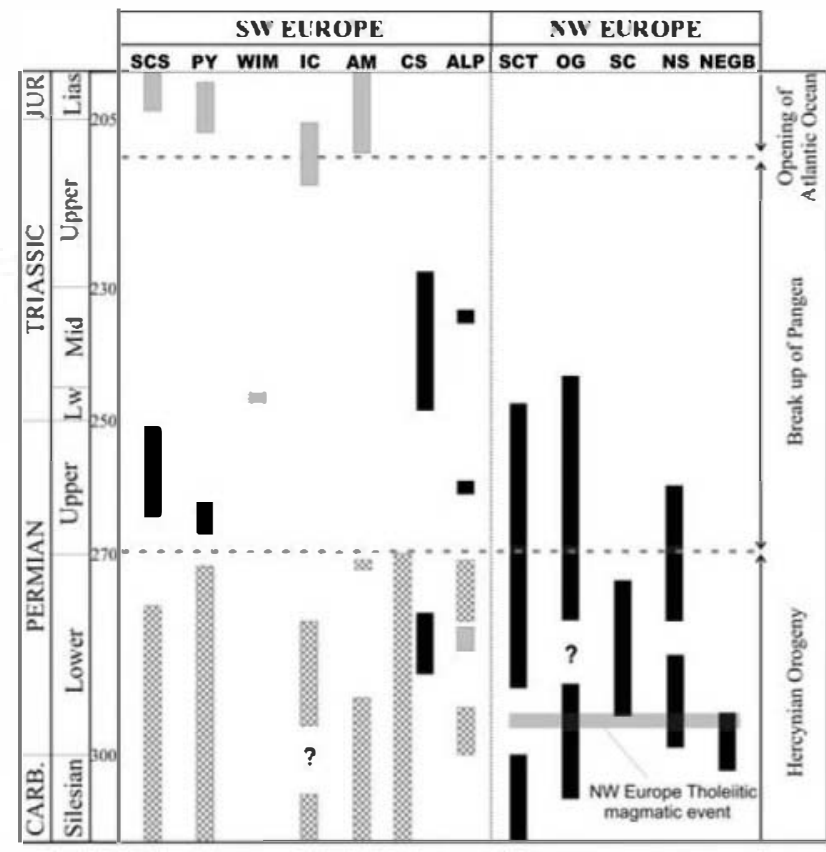

Calc-alkaline: peralurninous

Alkaline Tholeiitic

Fig. 12 Chronology of the main Permian-Triassic basic magmatism in westem Europe. PY Pyrenees, after Alibert (1985), Debon and Zimmermann (1993) and Lago et al. (2004); WIM West Iberian Margin, after Gardien and Paquette (2004); IC Iberian Chain, after Lago et al. (2005); AM Armorican Massif, after Bernard-Griffiths et al. (1985) and Bellon et al. (1988); CS Corsica-Sardinia, after Traversa et al. (2003), Bonin (2004) and Cocherie et al. (2005); ALP western and southem Alps, after Rottura et al. (1998), Eichhom et al. (2000), Carraro and Visonà (2003) and Monjoie (2004); SCT Scotland, after Upton et al. (2004); NS North Sea, after Stemmerik et al. (2000); NEGB North East German Basin, 0 Oslo Graben and SC Scania, after Neumann et al. (2004). NW Europe tholeiitic magmatic event at $295 \mathrm{Ma}$ are taken from Heeremans et al. (2004)

in Scania (294-274 Ma) and the NE German basin (294$302 \mathrm{Ma}$ ) (Neumann et al. 2004). A similar age range has been $\bullet$ btained for basic volcanics (strongly alkaline basalts and basanites) from the North Sea basins (broadly 299$260 \mathrm{Ma}$; Stemmerik et a1. 2000; Neumann et a1. 2004). Minor tholeiitic volcanics may accompany the more abundant alkaline røcks in NW Eurøpe Permø-Carbøniferøus regiøns. Mørever, a regiønal thølejitic magmatic event recorded around $295 \mathrm{Ma}$ characterizes these northern areas (Heeremans et al. 2004), but was not seen in SW Eurøpe (Fig. 12). On the ther hand, theleiitic magmas $\bullet$ ccur in SW Europe in continental areas at the Triassic-Jurassic boundary, as exemplified by the SCS and Pyrenees intrusions.

Accordingly, a geochemical contrast exists when cœmparing SW and NW Europe basic magmatism during the Permian. In SW Europe tholeiitic and alkaline magmatism is mostly absent during the Lower Permian (excepting Corsica-Sardinia; Fig. 12), whereas calc-alkaline magmatism is dominant and it does not appear in NW Europe. This discrepancy supports the possibility •utlined by Muttoni et al. (2003), that NW and SW Europe were geographically farther apart during the Early Permian than previously thought. The widespread alkaline magmatic event recorded in bøth SW and NW Eurøpe (SCS, PY, CS, ALP, SCT, ๑G, SC, NS and NEGB) during the Mid Permian might represent the assembly of all western Europe, to configure Pangea ' $A$ ' within the framewørk of a cømmon general geodynamic setting.

In the SCS, the intrusion of the alkaline suite during Upper Permian marks the change from the last Hercynian extensional stages to widespread post-Hercynian rifting. This latter gløbal faulting might represent the break up $\bullet$ Pangea, but it has als been linked to the $\bullet$ pening $\bullet$ the Atlantic Ocean and the development of the Central Atlantic Magmatic Province (Bonin 1988). This latter possibility could be supported by the alkaline-tholeiitic ransition during the Upper Triassic. This mainly •ccurs

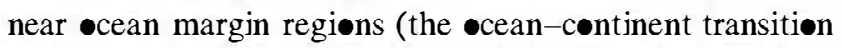
zone in the NW of the Iberian Massif and Armorican Massif; Fig. 12).

The marked change in the geochemical composition of the magmatism from Løwer t• Upper Permian in SW Europe, means the introduction of deeper mantle-derived melts with isøtopically depleted components, as evidenced by their positive $\varepsilon(N d)$ values (Corsica, Bønin 2004; western Alps, Monjøie 2004; Pyrenees, Lag• et al. 2004, and the SCS) (Fig. 7). Although this new is als• recorded in NW Eurøpe (Osl• Graben, Neumann et al. 2004; Scotland, Upton et al. 2004), it appears as early as $342 \pm 1 \mathrm{Ma}$ in Scotland (Monaghan and Pringle 2004), indicating a different ge $\bullet$ gical history for this northern sector when compared tø søuthern Eurøpe, reinf $\bullet$ rcing the geodynamic hypøthesis prøp॰sed abøve.

Permian alkaline melts frøm the SW Eurøpe (e.g. Cørsica-Sardinia, SCS area) display magma types with lower $\varepsilon N d$ values than NW Europe alkaline regions, plotting close to BSE (Fig. 7). Thus, an enriched lithospheric mantle component has been involved in the genesis of alkaline magmas in those southern Eurøpean areas (e.g. Perini et a1. 2004). This is in agreement with $\mathrm{Pb}$ isotope data, as discussed in the previous section. Nevertheless, Upper Permian alkaline magmatism in western Eurøpe is considered to be mainly derived from mantle sources without the involvement of significant subductioncontaminated components (Wilson et al. 2004). Intracontinental rifting at the end of the Hercynian or geny within central-western Europe has been suggested, implying lithosphere thinning and ascent of hot deep mantle (Wilsøn et a1. 2004 and references therein). Four possible mechanisms may account for this general process of rifting and associated mantle melting: (1) break off of a subducting slab; (2) delamination of the lower crust; (3) impingement -f a mantle plume; and (4) passive upwelling of 
asthenosphere as continental fragments diverge and melting eccurs by adiabatic decompression.

Models invelving crustal sinking (slab break off or løwer crustal delamination) are unlikely due to the absence of significant subduction-related components in the SCS lithospheric mantle sources.

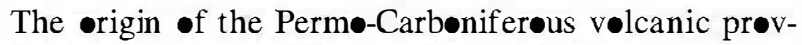
ince in Europe and NW Africa has been interpreted in terms of a superplume impinging on the base of the lithosphere (Ernst and Buchan 1997). According to this model, the head of this superplume would have spread northward asymmetrically from the incipient Atlantic rift (Oyarzun et al. 1997; Wilson 1997), covering a roughly elliptical area

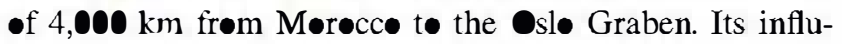
ence in western Europe is speculated to continue during Mesøric and Cenøzic times and is further related to the -pening of the Atlantic Ocean (e.g. Burke et al. 1973; White and McKenzie 1989; Oyarzun et a1. 1997). The small magma volumes represented by these alkaline dykes and the absence of magmatism between $252 \pm 3 \mathrm{Ma}$ (the youngest age determined for the SCS alkaline suite; Fernández Suárez et al. 2006) and $203 \pm 2$ Ma (intrusion of the tholeiitic Messejana-Plasencia dyke; Dunn et al. 1998) in central Spain, contradicts the classical theory of a deep mantle plume, continuously generating large magma volumes over a long periød of time (Campbell 2005 and

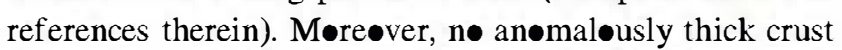
due to igneous accretion (underplating) of mafic rocks is known to have existed beneath the SCS. In fact, the composition of the lower crust seems to be felsic as indicated by the granulite xenoliths carried by the alkaline dykes (Villaseca et al. 1999). Recently, based on the absence of large magma volumes, thermal anomalies and low ${ }^{3} \mathrm{He} /{ }^{4} \mathrm{He}$ ratiøs, Kirstein et al. (2004) found n॰ compelling evidence of mantle plume involvement in the genesis of PermoCarboniferøus magmatism in NW Europe. This criticism with the plume model has als been extended to the opening of the central Atlantic Ocean (McHone 2000).

We suggest that the most probable geodynamic setting for the generation of the SCS alkaline magmas is that of lithosphere thinning, passive upwelling of hot asphenespheric mantle and melting forced by adiabatic decompression. Asthenosphere-like melts might be identified with the isopically depleted SCS dykes, whilst the lamprophyres with BSE-like is topic compositions are recording melting at the base of the lithosphere. The present lithospheric thickness in central Spain is around 110 km (Fernández et al. 1998; Tejer• and Ruiz 2002) and the region seems to have been tectonically stable since Permian times. More over, alkaline melt generation occurred at great depth (the stability field of gamet in peridotites ranges down to around $80 \mathrm{~km}$; Nickel 1986) close to the proposed lithosphere-asthenosphere boundary. The -ccurrence of alkaline mafic dykes in the western Alps at $260 \pm 1 \mathrm{Ma}$ (Monjøie 2004) has als been ascribed to melting of an asthenosphere-like mantle as a consequence of lithosphere thinning. The close similarities, which exist in the geochronoløgy and is tope geochemistry of the alkaline magmas from the SCS, Pyrenees and western Alps support the regional scale extension of this geodynamic context in søuthern Europe during the Permian.

\section{Summary and conclusions}

The alkaline lamprophyres and diabases from the SCS constitute a petrographically and geochemically hetergeneous suite of dykes. The abundance of mafic phenocrysts, the absence of primary magmas and presence -f variation trends characterized by decreasing $\mathrm{Ca}, \mathrm{Ti}, \mathrm{Ni}$,

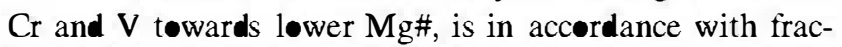
tionation of elivine + clinøpyroxene + kaersutite $\pm \mathrm{Cr}$ spinel \pm ulvospinel \pm plagioclase (this latter mineral only in the case of diabases).

Their bulk chemistry has not been influenced significantly by assimilation of crustal rocks, as their incompatible trace element ratios are similar to those of rocks typically derived from mantle sources $(\mathrm{Ce} / \mathrm{Pb}$ and $\mathrm{Ba} / \mathrm{Nb}$ in OB and MORB). Moreover, they do not show positive correlation of silica content with $\mathrm{Rb} / \mathrm{Sr}$ or ${ }^{87} \mathrm{Sr} /{ }^{86} \mathrm{Sr}$ ratios.

The clear positive $\mathrm{Nb}-\mathrm{Ta}$ and negative $\mathrm{Pb}$ anomalies indicate that enrichment of their sources was not caused by any subduction-related component. The highly fractionated chondrite-normalised REE patterns and high $\mathrm{Sm} / \mathrm{Yb}_{\mathbf{N}}$ ratios suggest that they formed within the garnet stability field. The potassic nature of the SCS lamprophyres and their $\mathrm{Rb} / \mathrm{La}$ and $\mathrm{K} / \mathrm{La}$ ratios pøint to phlogøpite dominating their generation, whereas amphibole prevailed in the case of the sodic diabases. It is likely that the enrichment event was caused by infiltration of $\mathrm{K}$ - and volatile-rich fluids or melts. The high REE contents shown by the is opically depleted dykes imply that melting occurred shortly after metasomatism.

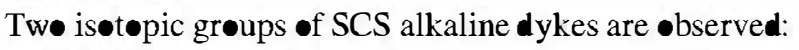
(1) a PREMA-like (asthenøsphere) comp»nent $(\varepsilon \mathrm{Nd}=+4$

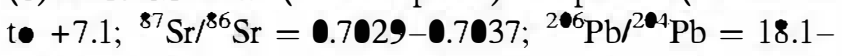
18.5); and (2) a BSE-like or slightly enriched lithospheric component $\left(\varepsilon N d=+1.4\right.$ to $-0.9 ;{ }^{87} \mathrm{Sr} /{ }^{86} \mathrm{Sr}=0.7043-$ $\left.0.7051 ;{ }^{206} \mathrm{~Pb} /{ }^{204} \mathrm{~Pb}=18.3-18.5\right)$. The slight enrichment in ${ }^{87} \mathrm{Sr},{ }^{207} \mathrm{~Pb}$ and ${ }^{208} \mathrm{~Pb}$ is tope ratios can be ascribed to the introduction int the mantle sources of continental or subduction-modified components.

A clear geochemical contrast can be observed when comparing lower Permian basic magmatism from SW and NW Eurøpe. In areas north of the Hercynian frønt, n॰ 
calc-alkaline or peraluminøus magmatism is recorded at that time and alkaline manifestations are widespread. In areas affected by the Hercynian orogeny alkaline magmas are scarce before Upper Permian times. Moreover, northern areas show a regional tholeiitic event around $295 \mathrm{Ma}$, which does not exist in SW Europe. This difference agrees with the model outlined by Muttoni et al. (2003) in which NW and SW Europe were geøgraphically assembled during mid Permian times.

Though a mantle plume has been proposed as the principal factor responsible for the rifting process during Permo-Carboniferøus times there are features that are not in accordance with this model when applied the SCS. This has als been argued for the magmatism in Northern Europe (e.g. Kirstein et a1. 2004, 2006). Thus we favor a passive model in which rifting would follow from lithosphere thinning and upwelling of the hot asthenosphere. This tectonic regime might be ransitional between the general Perm॰-Carboniferøus extension in western Eurøpe and the final opening of the Atlantic Ocean during the Mesozeic.

Acknowledgments We acknowledge Alfredo Fernández Larios and José González del Tánago for their assistance with the electron microprobe analyses in the CAI of Microscopía Electrónica (UCM). We also thank Rex Taylor and Tyna Hayes from the Southampton Oceanography centre, for their help in analysing samples by TIMS. The Access to Research Infrastructure action of the Improving Human Potential Programme, supported by the European Community, has let us carry out the laser mineral analyses at the University of Bristol, the $\mathrm{Pb}$ isotope analyses at the Swedish Museum of Natural History and part of the $\mathrm{Sr}-\mathrm{Nd}$ isotope analyses at the National -ceanography Centre of Southampton. This work is included in the objectives of, and supported by, the CGL2004-02515 project of the Ministerio de Educación y Ciencia of Spain.

\section{References}

Alibert C (1985) A Sr-Nd isotope and REE study of late Triassic dolerites from the Pyrenees (France) and the Messe jana dyke (Spain and Portugal). Earth Planet Sci Lett 73:81-90

Bea F, Montero P, Molina JF (1999) Mafic precursors, peraluminous granitoids, and late lamprophyres in the Avila batholith; a model for the generation of Variscan batholiths in Iberia. J Geol 107:399-419

Bellon H, Chauris L, Hallegouet B, Thonon P (1988) Magmatisme fissural permien et riasique dans le Pays de Léon (Massif armoricain, France). C R Géosci 307:2049-2054

Bernard-Griffiths J, Peucat JJ, Sheppard S, Vidal P (1985) Petrogenesis of Hercynian leucogranites from the southem Armorican Massif: contribution of REE and isotopic ( $\mathrm{Sr}, \mathrm{Nd}, \mathrm{Pb}$ and $\mathrm{O}$ ) geochemical data to the study of source rock characteristics and ages. Earth Planet Sci Lett 74:235-250

Bonin B (1988) From orogenic to anorogenic environments: evidence from associated magmatic episodes. Schweiz Mineral Petrogr Mitt 68:301-311

Bonin B (2004) Do coeval mafic and felsic magmas in postcollisional to within-plate regimes necessarily imply two contrasting, mantle and crustal, sources? A review. Lithos 78:1-24
Burke K, Kidd WSF, Wilson JT (1973) Relative and latitudinal motion of Atlantic hot spots. Nature 245:133-138

Campbell IH (2005) Large igneous provinces and the mantle plume hypothesis. Elements 1:265-269

Carignan J,HildP, Mevelle G,Morel J, Yeghicheyan D (2001) Routine analyses of trace elements in geological samples using flow in jection and low pressure on-line liquid chromatography coupled to ICP-MS; a study of geochemical reference materials BR, DR-N, UB-N, AN-G and GH. Geostand Newslett 25:187-198

Canaro A, Visonà D (2003) Mantle xenoliths in Triassic camptonite dykes of the Predazzo area (Dolomites, northern Italy); petrography, mineral chemistry and geothennobarometry. Eur J Mineral 15:103-115

Casillas R, Vialette Y, Peinado M, Duthou J, Pin C (1991) Ages et caractéristiques isotopiques $(\mathrm{Sr}, \mathrm{Nd})$ des granitoides de la Sierra de Guadarrama occidentale (Espagne). Abstract Séance Spécialisée Soc. Géol. France Mém. Jean Lameyre, s/n

Chalapatbi Rao NV, Gibson SA, Pyle DM, Dickin AP (2004) Petrogenesis of Proterozoic lamproites and kimberlites from the Cuddapah basin and Dharwar craton, Southem India. J Petrol 45:907-948

Cocherie A, Rossi P, Fanning CM, Guerrot C (2005) Comparative use of TIMS and SHRIMP for U-Pb zircon dating of A-type granites and mafic tholeiitic layered complexes and dykes from the Corsican Batholith (France). Lithos 82:185-219

Cortesogno L, Cassinis G, Dallagiovanna G, Gaggero L, Oggiano G, Ronchi A, Seno S, Vanossi M (1998) The Variscan postcollisional volcanism in Late Carboniferous-Permian sequences of Ligurian Alps, Sourthem Alps and Sardinia (Italy): a synthesis. Lithos 45:305-328

Debon F, Zimmermann JL (1993) Mafic dykes from some plutons of the westem Pyrenean Axial Zone (France, Spain): markers of the ransition from late-Hercynian to early-Alpine events. Schweiz Mineral Petrogr Mitt 73:421-433

Doblas M, Oyarzun R, López-Ruiz J, Cebriá JM, Youbi N, Mahecha V, Lago M, Pocoví A, Cabanis B (1998) Permo-Carboniferous volcanism in Europe and northwest Africa: a superplume exhaust valve in the centre of Pangaea? J African Earth Sci 26:89-99

Dostal J, Dupuy C, Carron JP, Dekemeizon ML, Maur RC (1983) Partition coefficients of trace elements: application to volcanic rocks of St Vincent, West-Indies. Geochim Cosmochim Acta 47:525-533

Dunn AM, Reynolds PH, Clarke DB, Ugidos JM (1998) A companison of the age and composition of the Sherburne Dyke, Nova Scotia, and the Messejana Dyke, Spain. Can J Earth Sci 35:1110-1115

Eichhom R, Loth G, Höll R, Finger F, Schennaier A, Kennedy A (2000) Multistage Variscan magmatism in the central Tauem Window (Austria) unveiled by U/Pb SHRIMP zircon data. Contrib Mineral Petrol 139:418-435

Emst RE, Buchan KL (1997) Giant radiating dyke swarms: their use in identifying pre-Mesozoic large igneous provinces and mantle plumes. In: Mahoney JJ, Coffin MF (eds) Large igneous provinces. Continental, oceanic, and planetary flood volcanism AGU Geophysical Monograph 100, pp 297-333

Fernández Suárez J, Arenas R, Jeff ries TB, Whitehouse MJ, Villaseca C (2006) A U-Pb study of zircons from a lower crustal granulite xenolith of the Spanish Central system: a record of Iberian lithospheric evolution from the Neoproterozoic to the Triassic J Geol 114:471-483

Fernández M, Marzán I, Correia A, Ramalho E (1998) Heat flow, heat production, and lithospheric thennal regimen in the Iberian Peninsula. Tectonophysics 291:29-53

Foley SF (1992) Petrological characterization of the source compo nents of potassic magmas: geochemical and experimental constraints. Lithos 28:187-204 
Foley SF, Venturelli G, Green $\mathbf{D H}$, Toscani L (1987) The ultrapotassic rocks; characteristics, classification, and constraints for petrogenetic models. Earth-Sci Rev 24:81-134

Foley SF, Jackson SE, Fryer BJ, Greenough JD, Jenner GA (1996) Trace element partition coefficients for clinopyroxene and phlogopite in an alkaline lamprophyre from Newfoundland by LAM-ICP-MS. Geochim Cosmochim Acta 60:629-638

Franke W (1989) Variscan plate tectonics in central Europe: current ideas and open questions. Tectonophysics 169:221-228

Frey FA, Green DH, Roy SD (1978) Integrated models of basalt petrogenesis: a study of quartz tholeiites to olivine melilitites from south eastern Australia utilizing geochemical and experimental petrological data. J Petrol 19:463-513

Galindo C, Huertas MJ, Casquet C (1994) Cronología Rb-Sr y K-Ar de diques de la Sierra de Guadarrama (Sistema Central Español). Geogaceta 16:23-26

Gardien V, Paquette JL (2004) Ion microprobe and ID-TIMS U-Pb dating on zincon grains from leg 173 amphibolites: evidence for Permian magmatism on the West Iberian margin. Terra Nova $16: 226-231$

Govindaraju K (1994) Compilation of working values and sample description for 383 geostandards. Geostand Newslett 18:1-158

Green TH (1995) Significance of Nb/ Гa as an indicator of geochemical processes in the crust-mantle system. Chem Geol 120:347359

Gutiérrez Marco JC, San José MA, Pieren AP (1990) Central-Iberian Zone. Post-Cambrian Paleozoic stratigraphy. In: Dalhneyer RD, Martínez García E (eds) Pre-Mesozoic geology of Iberia. Springer, Berlín, pp 160-171

Hart SR, Dunn T (1993) Experimental cpx/melt partitioning of 24 trace elements. Contrib Mineral Perol 113:1-8

Hawkesworth CJ, Kempton PD, Rogers NW, Ellam RM, van Calsteren PW (1990) Continental mantle lithosphere, and shallow level enrichment processes in the earth's mantle. Earth Planet Sci Lett 96:256-268

Heeremans M, Faleide J, Larsen BT (2004) Late CarboniferousPermian of NW Europe: an introduction to a new regional map. In: Wilson M, Neumann ER, Davies GR, Timmerman MJ, Heeremans M, Larsen B (eds) Permo-Carboniferous magmatism and rifting in Europe. Geol Soc London Spec Publ, vol 223, London, pp 75-88

Ionov DA, Griffin WL, O'Reilly SY (1997) Volatile-bearing minerals and lithophile race elements in the upper mantle. Chem Geol 141:153-184

Irving AJ, Frey FA (1984) Trace element abundances in megacrysts and their host basalts; constraints on partition coefficients and megacryst genesis. Geochim Cosmochim Acta 48:1201-1221

Irving E (1977) Drift of the major continental blocks since the Devonian. Nature 270:304-309

Kirstein LA, Dunai T, Davies G, Upton BJ, Nikogosian IK (2004) Evidence of heterogeneous mantle beneath Scotland during the Permo-Carboniferous from helium isotopes. In: Wilson $\mathbf{M}$, Neumann ER, Davies GR, Timmennan MJ, Heeremans M, Larsen B (eds) Penno-Carboniferous magmatism and rifting in Europe. Geol Soc London Spec Publ, vol 223, London, pp 243-258

Kirstein LA, Davies GR, Heeremans M (2006) The petrogenesis of Carboniferous-Permian dyke and sill intrusions across northem Europe. Contrib Mineral Perol 152:721-742

Lago M, Arranz E, Pocoví A, Galé C, Gil-Imaz A (2004) Perrnian magmatism and basin dynamics in the southem Pyrenees: a record of the transition from late Variscan ranstension to early Alpine extension. In: Wilson M, Neumann ER, Davies GR, Timmerman MJ, Heeremans M, Larsen B (eds) Permo-Carboniferous magmatism and rifting in Europe. Geol Soc London Spec Publ, vol 223, London, pp 439-464
Lago M, Gil A, Arranz E, Galé C, Pocoví A (2005) Magmatism in the intracratonic Central Iberian basins during the Permian: Palaeoenvironmental consequences. Palaeo 229:83-103

LaTourrette T, Hervig RL, Holloway JR (1995) Trace element partitioning between amphibole, phlogopite, and basanite melt. Earth Planet Sci Lett 135:13-30

Leake BE, Woolley AR, Arps CES, Birch WD, Gilbert MC, Grice JD, Hawthome FC, Kato A, Kisch HJ, Krivovichev VG, Linthout K, Laird J, Mandarino JA, Maresch WV, Nickel EH, Rock NMS, Schumacher JC, Smith DC, Stephenson NCN, Ungaretti L, Whittaker EJW, Youzhi G (1997) Nomenclature of amphiboles; report of the subcommittee on amphiboles of the International Mineralogical Association, Commission on New Minerals and Mineral Names. Can Mineral 35:219-246

Le Bas MJ, Le Maitre RW, Streckeisen A, Zanettin B (1986) A chemical classification of volcanic rocks based on the total alkali-silica diagram. J Petrol 27:745-750

Le Maire RW, Streckeisen A, Zanettin B, Le Bas MJ, Bonin B, Bateman P, Bellieni G, Dudek A, Efremova S, Keller J, Lameyre J, Sabine PA, Schmid R, Sorensen H, Woolley AR (2002) Igneous rocks: a classification and glossary of terms. Cambridge University Press, Cambridge, pp 236

Matsui Y, Onuma N, Nagasawa H, Higuchi H, Banno S (1977) Crystal structure control in trace element partition between crystal and magma. Tectonics 100:315-324

McDonough WF, Sun SS (1995) The composition of the Earth. Chem Geol 120:223-253

McHone JG (2000) Non-plume magmatism and rifting during the opening of the central Atlantic acean. Tectonophysics 316:287296

McKenzie (1989) Some remarks on the movement of small melt fractions in the mantle. Earth Planet Sci Lett 95:53-72

McKenzie D, O'Nions RK (1991) Partial melt distributions from inversion of rare earth element concentrations. J Petrol 32:10211091

Monaghan AA, Pringle MS (2004) ${ }^{4} \mathrm{Ar} /{ }^{39} \mathrm{Ar}$ geochronology of Carboniferous-Permian volcanism in the Midland Valley, Scotland. In: Wilson M, Neumann ER, Davies GR, Timmerman MJ, Heeremans M, Larsen B (eds) Permo-Carboniferous magmatism and rifting in Europe. Geol Soc London Spec Publ, vol 223, London, pp 219-241

Monjoie P (2004) The Mont Collon mafic complex (Austroalpine Dent Blanche nappe). Doctoral Thesis, University of Lausanne, pp 163

Morimoto N, Fabries J, Ferguson AK, Ginzburg IV, Ross M, Seifert FA, Zussman J, Aoli K, Gottardi G (1988) Nomenclature of pyroxenes. Am Mineral 73:1123-1133

Muttoni G, Kent $\mathbf{D V}$, Garzanti E, Brack P, Abrahamsen N, Gaetani M (2003) Early Permian Pangea 'B' to Late Permian Pangea 'A' Earth Planet Sci Lett 215:379-394

Navon -, Stolper E (1987) Geochemical consequences of melt percolation; the upper mantle as a chromatographic column. J Geol 95:285-307

Neumann ER, Wilson M, Heeremans M, Spencer EA, Obst K, Timmerman MJ, Kirstein L (2004) Carboniferous-Permian rifting and magmatism in southern Scandinavia, the North Sea and northern Germany: a review. In: Wilson M, Neumann ER, Davies GR, Timmerman MJ, Heeremans M, Larsen B (eds) Permo-Carboniferous magmatism and rifting in Europe. Geol Soc London Spec Publ, vol 223, London, pp 11-40

Nickel KG (1986) Phase equilibria in the system $\mathrm{Si} 2-\mathrm{Mg}-\mathrm{Al}_{2} \mathbf{O}_{3}-$ $\mathrm{Ca}-\mathrm{Cr}_{2} \mathrm{O}_{3}$ (SMACCr) and their bearing on spinel/garnet lherzolite relationships. Neues Jahrb Mineral Abh 155:259-287

Obst K, Solyom Z, Johansson L (2004) Permo-Carboniferous extension-relate magmatism at the SW margin of the Fennoscandian Shield. In: Wilson M, Neumann ER, Davies GR, 
Timmerman MJ, Heeremans M, Larsen B (eds) Permo-Carboniferous magmatism and rifting in Europe. Geol Soc London Spec Publ, vol 223, London, pp 259-288

Orejana D, Villaseca C (2008) Heterogeneous metasomatism in cumulate xenoliths from the Spanish Cen ral System: implications on percolative factional crystallization of lamprophyric melts. In: Coltorti M, Gregoire M (eds) Metasomatism in oceanic and continental lithospheric mantle. Geol Soc London Spec Publ, vol 293, London, pp 101-120

Orejana D, Villaseca C, Billström K (2005) A PREMA asthenospheric component for the Permian alkaline dykes of the Spanish Central System. Geochim Cosmochim Acta 69 (Supp 1):A855

-rejana D, Villaseca C, Paterson BA (2006) Geochemistry of pyroxenitic and homblenditic xenoliths in alkaline lamprophyres from the Spanish Central System. Lithos 86:167-196

Orejana D, Villaseca C, Paterson BA (2007) Geochemistry of mafic phenocrysts from alkaline lamprophyres of the Spanish Central System: implications on crystal fractionation, magma mixing and xenoliths entrapment within deep magma chambers. Eur $\mathbf{J}$ Mineral 19:817-832

-yarzun R, Doblas M, López-Ruiz J, Cebriá JM (1997) Ppening of the central Atlantic and asymmetric mantle upwelling phenomena: implications for long-lived magmatism in westem North Africa and Europe. Geology 25:727-730

Peacock SM (1990) Fluid processes in subduction zones. Science 248:329-337

Perini G, Cebriá JM, López-Ruiz JM, Doblas M (2004) PermoCarboniferous magmatism in the variscan belt of Spain and France: implications on mantle sources. In: Wilson M, Neumann ER, Davies GR, Timmerman MJ, Heeremans M, Larsen B (eds) Permo-Carboniferous magmatism and rifting in Europe. Geol Soc London Spec Publ, vol 223, London, pp 415-438

Portugal-Ferreira M, Macedo CR (1977) Actividade basaltica Permico-Liassica no territorio portugues; uma achega para a datacao. Permo-Liassic basaltic activity in Portugal; preliminary dating. Mem Not Publ Museo Lab Min Geol Univ Coimbra $8339-52$

Ringwood AE (1970) Petrogenesis of Apollo 11 basalts and implications for lunar origin. J Geoph Res 75.6453-6479

Rock NMS (1991) Lamprophyres. Blackie, Glasgow, pp 285

Rottura A, Bargossi GM, Caggianelli A, Del Moro A, Visona D, Tranne CA (1998) Origin and significance of the Permian high-K calc-alkaline magmatism in the central-eastern Southem Alps, Italy. Lithos $45329-348$

Rudnick RL, Gao S (2003) Composition of the continental crust. In: Holland HD, Turekian KK (eds) Treatise on Geochemistry 3. The crust. Elsevier, Pergamon, Oxford, pp 1-64

Scarrow JH, Bea F, Montero P, Molina JF, Vaughan APM (2006) A precise late Permian ${ }^{40} \mathrm{Ar} /{ }^{39} \mathrm{Ar}$ age for Central Ibetian camptonitic lamprophyres. Geol Acta 4:451-459

Stemmerik L, Ineson JR, Mitchell JG (2000) Stratigraphy of the Rotliegend Group in the Danish part of the northem Permian Basin, North Sea. J Geol Soc Lond 157:1127-1136

Sun SS, McDonough WF (1989) Chemical and isotopic systematics of oceanic basalts; implications for mantle composition and processes. In: Saunders AD, Norrey MJ (eds) Magmatism in ocean basins. Blackwell, Geol Soc Spec Publ, vol 42, Oxford, pp 313-345

Taura H, Yurimoto H, Kurita K, Sueno S (1998) Pressure dependence on partition coefficients for race elements between olivine and the coexisting melts. Phys Chem Earth 25:469-484

Tejero R, Ruiz J (2002) Thermal and mechanical structure of the cen ral Iberian Peninsula lithosphere. Tectonophysics 350:49-62

Tiepolo M, Vannucci R, Oberti R, Foley SF, Bottazzi P, Zanettj A (2000) $\mathrm{Nb}$ and $\mathrm{Ta}$ incorporation and fractionation in titanian pargasite and kaersutite: crystal-chemical constraints and implications for natural systems. Earth Planet Sci Lett 176:185-201

Traversa G, Ronca S, Del Moro A, Pasquali C, Buraglini N, Barabino G (2003) Late to post-Hercynian dyke activity in the SardiniaCorsica domain: a ransition from orogenic calc-alkaline to anorogenic alkaline magmatism. Boll Soc Geol It Vol Spec $2: 131-152$

Ubanell A G (1981) Significado tectónico de los principales sistemas de diques en un sector del Sistema Central Español. Cuad Geol Iber 7:607-622

Upton BGJ, Stephenson D, Smedley PM, Wallis SM, Fitton JG (2004) Carboniferous and Permian magmatism in Scotland. In: Wilson M, Neumann ER, Davies GR, Timmerman MJ, Heeremans $\mathbf{M}$, Larsen $\mathbf{B}$ (eds) Permo-Carboniferous magmatism and rifting in Europe. Geol Soc London Spec Publ, vol 223, London, pp 195-218

Villaseca C, Herreros V (2000) A sustained felsic magmatic system: the Hercynian granitic batholith of the Spanish Central System. Edinburgh Geol Soc Trans Earth Sci 91:207-219

Villaseca C, Barbero L, Reyes J, Santos Zalduegui JF (1998a) Nuevos datos petrológicos, geocronología $(\mathbf{R b}-\mathrm{Sr})$ y geoquímica isotópica $(\mathrm{Sr}, \mathrm{Nd}$ ) del plutón de Ventosilla (Sierra de Guadarrama, Sistema Central Español). Geogaceta 23:16 -172

Villaseca C, Barbero L, Rogers G (1998b) Crustal origin of Hercynian peraluminous granitic batholiths of central Spain: perological, geochemical and isotopic ( $\mathrm{Sr}, \mathrm{Nd}$ ) arguments. Lithos 43:55-79

Villaseca C, Downes H, Pin C, Barbero L (1999) Nature and composition of the lower continental crust in central Spain and the granulite-granite linkage: inferences from granulitic xenoliths. J Perol 40:1465-1496

Villaseca C, Orejana D, Pin C, López García JA, Andonaegui P (2004) Le magmatisme basique hercynien et post-hercynien du Système Central Espagnol: essai de caractèrisation des sources manteliques. C R Géosci 336:877-888

White R, McKenzie $\mathbf{D}$ (1989) Magmatism at rift zones: the generation of volcanic continental margins and flood basalts. J Geoph Res 94:7685-7729

Wilson M (1989) Igneous petrogenesis: a global tectonic approach. Unwin Hyman, Boston, pp 466

Wilson M (1997) Thermal evolution of the central Atlantic passive margins: continental break-up above a Mesozoic super-plume. J Geol Soc Lond 154:491-495

Wilson M, Neumann ER, Davies GR, Timmerman MJ, Heeremans M, Larsen B T (2004) Permo-Carboniferous magmatism and rifting in Europe. Geol Soc London Spec Publ, vol 223, London, pp 498

Zanettj. A, Tiepolo M, Oberti R, Vannucci R (2004) Trace-element partitioning in olivine: modelling of a complete data set from a synthetic hydrous basanite melt. Lithos $7539-54$

Zeck HP, Wingate MTD, Pooley G (2007) Ion microprobe U-Pb zircon geochronology of a late tectonic granitic-gabbroic rock complex within the Hercynian Iberian belt. Geol Mag 144:157177

Ziegler PA (1993) Late Palaeozoic-Early Mesozoic plate reorganization: evolution and demise of the Variscan fold belt. In: Von Raumer JF, Neubauer F (eds) Pre-Mesozoic geology in the Alps. Springer, Berlin, pp 203-216

Ziegler PA, Schumacher ME, Dézes $\mathbf{P}$, vam Wees J-D, Cloetingh S (2004) Post-Variscan evolution of the lithosphere in the Rhine Graben area: constraints from subsidence modelling. In: Wilson M, Neumann ER, Davies GR, Timmerman MJ, Heeremans M, Larsen BT (eds) Permo-Carboniferous magmatism and rifting in Europe. Geol Soc London Spec Publ, vol 223, London, pp 289-317

Zindler A, Hart SR (1986) Chemical geodynamics. Arn Rev Earth Planet Sci 14:493-571 